\title{
Decreased Cocaine Motor Sensitization and Self-Administration in Mice Overexpressing Cannabinoid $\mathrm{CB}_{2}$ Receptors
}

\author{
Auxiliadora Aracil-Fernández ${ }^{1,2}$, José M Trigo ${ }^{2,3}$, María S García-Gutiérrez ${ }^{1,2}$, Antonio Ortega-Álvaro ${ }^{4}$, \\ Alexander Ternianov", Daniela Navarro', Patricia Robledo ${ }^{2,3,5}$, Pere Berbel', Rafael Maldonado ${ }^{2,3}$ \\ and Jorge Manzanares*,1,2 \\ 'Instituto de Neurociencias, Universidad Miguel Hernández-CSIC, Avenida Ramón y Cajal s/n, Alicante, Spain; ${ }^{2}$ Red Temática de Investigación \\ Cooperativa en Salud (RETICS-Trastornos Adictivos), Instituto de Salud Carlos III, MICINN and FEDER, Madrid, Spain; ${ }^{3}$ Laboratori de \\ Neurofarmacología, Universitat Pompeu Fabra, Barcelona, Spain; ${ }^{4}$ Unidad de Neuropsicofarmacología Traslacional, Complejo Hospitalario \\ Universitario de Albacete, Albacete, Spain; ${ }^{5}$ Neuropsychopharmacology Research Program, IMIM (Hospital del Mar Research Institute), PRBB, \\ Barcelona, Spain
}

\begin{abstract}
The potential involvement of the cannabinoid $C_{2}$ receptors $\left(C_{2} r\right)$ in the adaptive responses induced by cocaine was studied in transgenic mice overexpressing the $\mathrm{CB}_{2} r\left(\mathrm{CB}_{2} \times \mathrm{P}\right)$ and in wild-type (WT) littermates. For this purpose, the acute and sensitized locomotor responses to cocaine, conditioned place preference, and cocaine intravenous self-administration were evaluated. In addition, we assessed whether $\mathrm{CB}_{2} r$ were localized in neurons and/or astrocytes, and whether they colocalized with dopamine DI and D2 receptors (DIDr and D2Dr). Dopamine (DA) extracellular levels in the nucleus accumbens (NAcc), and gene expression of tyrosine hydroxylase (TH) and DA transporter (DAT) in the ventral tegmental area (VTA), and $\mu$-opioid and cannabinoid $\mathrm{CB}_{\text {I }}$ receptors in the NAcc were also studied in both genotypes. $\mathrm{CB}_{2} \times \mathrm{P}$ mice showed decreased motor response to acute administration of cocaine $(10-20 \mathrm{mg} / \mathrm{kg})$ and cocaine-induced motor sensitization compared with WT mice. CB $\mathrm{B}_{2} \times \mathrm{P}$ mice presented cocaine-induced conditioned place aversion and self-administered less cocaine than WT mice. $\mathrm{CB}_{2} r$ were found in neurons and astrocytes and colocalized with D2Dr in the VTA and NAcc. No significant differences in extracellular DA levels in the NAcc were observed between genotypes after cocaine administration. Under baseline conditions, TH and DAT gene expression was higher and $\mu$-opioid receptor gene expression was lower in $\mathrm{CB}_{2} \times \mathrm{P}$ than in WT mice. However, both genotypes showed similar changes in $\mathrm{TH}$ and $\mu$-opioid receptor gene expression after cocaine challenge independently of the pretreatment received. Importantly, the cocaine challenge decreased DAT gene expression to a lesser extent in cocaine-pretreated $\mathrm{CB}_{2} \times \mathrm{P}$ than in cocaine-pretreated WT mice. These results revealed that $\mathrm{CB}_{2} r$ are involved in cocaine motor responses and cocaine self-administration, suggesting that this receptor could represent a promising target to develop novel treatments for cocaine addiction.

Neuropsychopharmacology (2012) 37, 1749-1763; doi:I0.1038/npp.2012.22; published online I4 March 2012
\end{abstract}

Keywords: cocaine; cannabinoid; dopamine transporter; sensitization; self-administration; tyrosine hydroxylase

\section{INTRODUCTION}

A large body of evidence suggests the involvement of the endocannabinoid system (ECS) in the development of dependence to different licit and illicit drugs (Fattore et al, 2007; Lupica et al, 2004; Maldonado et al, 2006; Parolaro and

\footnotetext{
*Correspondence: Dr J Manzanares, Instituto de Neurociencias, Universidad Miguel Hernández-CSIC, Avenida Ramón y Cajal s/n, Alicante 03550, Spain, Tel: + 349659 | 9248, Fax: + 34965919549 , E-mail: jmanzanares@umh.es

Received 5 August 2011; revised 10 February 2012; accepted 13 February 2012
}

Rubino, 2008; Tanda and Goldberg, 2003). However, the specific participation of the ECS in cocaine addiction remains unclear. Thus, the administration of a cannabinoid $\mathrm{CB}_{1}$ receptor $\left(\mathrm{CB}_{1} \mathrm{r}\right)$ antagonist or the deletion of $\mathrm{CB}_{1} \mathrm{r}$ does not alter cocaine self-administration in rodents (Cossu et al, 2001), conditioned place preference (CPP) or behavioral sensitization (Lesscher et al, 2005; Martin et al, 2000). Other studies revealed that the administration of a cannabinoid $\mathrm{CB}_{1} \mathrm{r}$ agonist induced relapse to cocaine-seeking behavior (De Vries et al, 2001), and $\mathrm{CB}_{1} \mathrm{r}$ antagonists inhibited sensitized locomotor response to a cocaine challenge (Filip et al, 2006) and cocaine self-administration (Soria et al, 2005; $\mathrm{Xi}$ et al, 2008). In addition, the deletion of $\mathrm{CB}_{1} \mathrm{r}$ 
decreased cocaine-induced motor sensitization (Corbille et al, 2007), CPP (Miller et al, 2008) and the breakpoint for cocaine self-administration (Soria et al, 2005).

There is scarce information about the possible involvement of cannabinoid $\mathrm{CB}_{2}$ receptors $\left(\mathrm{CB}_{2} \mathrm{r}\right)$ in cocaine dependence. Initially, $\mathrm{CB}_{2} \mathrm{r}$ were found in the brain only under pathological conditions (Ehrhart et al, 2005; Guzman et al, 2001; Ibrahim et al, 2003). However, further descriptive studies in rodents reported $\mathrm{CB}_{2} \mathrm{r}$ gene expression in the different areas of brain under baseline conditions, caudate putamen, nucleus accumbens (NAcc), cingulate cortex, amygdala, hippocampus, ventromedial hypothalamic nucleus, arcuate nucleus, thalamus, substantia nigra, dorsal raphe, and medial raphe nucleus (Garcia-Gutierrez et al, 2010; Onaivi, 2006; Van Sickle et al, 2005). Furthermore, the presence of $\mathrm{CB}_{2} \mathrm{r}$ in reward-related brain areas such as the ventral tegmental area (VTA) and the NAcc suggests the participation of this receptor in drug abuse.

A number of results support the potential implication of $\mathrm{CB}_{2} \mathrm{r}$ in addictive behaviors. Increased $\mathrm{CB}_{2} \mathrm{r}$ gene expression was reported in the brain of mice after chronic treatment with heroin or cocaine (Onaivi et al, 2008). In contrast, the same group reported reduced $\mathrm{CB}_{2} \mathrm{r}$ gene expression in striatum and ventral midbrain after chronic ethanol intake in mice (Onaivi et al, 2008). Furthermore, the pharmacological manipulation of $\mathrm{CB}_{2} \mathrm{r}$ modified ethanol intake only in stressed mice (Ishiguro et al, 2007). It is possible that $\mathrm{CB}_{2} \mathrm{r}$ and $\mathrm{CB}_{1} \mathrm{r}$ function together regulating dopaminergic circuits involved in drug-induced motivation and reward. Drugs of abuse act directly on dopaminergic terminals or block GABAergic inhibitory neurons on cell bodies of mesolimbic dopaminergic neurons, increasing the release of dopamine (DA) in the NAcc (Nestler, 2001; Spanagel and Weiss, 1999; Tanda et al, 1997). In contrast, drug withdrawal decreases mesolimbic DA neuronal activity (Spanagel and Weiss, 1999), reduces spontaneous firing rate of DA neurons in the VTA (Diana et al, 1998), and decreases tyrosine hydroxylase (TH) gene expression in the VTA (Oliva et al, 2003). The regulation of DA neuronal activity involves the participation of the DA transporter (DAT), which regulates DA reuptake from the synaptic cleft determining the intensity and duration of DA activity (Gainetdinov et al, 2003; Jaber et al, 1997) and TH, the ratelimiting enzyme of DA biosynthesis (Jaber et al, 1999; Jones et al, 1998). In addition, several reports revealed the participation of the $\mu$-opioid receptor (Chefer et al, 2004; Hall et al, 2004; Hummel et al, 2004; Yoo et al, 2003) and the $\mathrm{CB}_{1} \mathrm{r}$ in the relapse to cocaine-seeking (De Vries et al, 2001) and in the rewarding effects of other drugs of abuse (Onaivi, 2008; Parolaro and Rubino, 2008), suggesting a functional interaction between opioid and cannabinoid systems in addiction-related behavioral responses (Manzanares et al, 1999; Navarro et al, 2001; Paldyova et al, 2008).

To explore the potential involvement of $\mathrm{CB}_{2} \mathrm{r}$ in the adaptive responses underlying addictive processes, several behavioral and neurochemical responses induced by cocaine were studied in the wild-type (WT) and transgenic mice overexpressing $\mathrm{CB}_{2} \mathrm{r}\left(\mathrm{CB}_{2} \mathrm{xP}\right)$. The overexpression of $\mathrm{CB}_{2} \mathrm{r}$ in $\mathrm{CB}_{2} \mathrm{xP}$ mice has been identified in caudate putamen $(150 \%)$, NAcc $(180 \%)$, cingulate cortex $(199 \%)$, amygdala (64\%), hippocampus (158\%), ventromedial thalamic nucleus $(126 \%)$, arcuate nucleus (157\%), substantia nigra
(278\%), VTA (100\%), dorsal raphe (50\%), and medial raphe nucleus (57\%) compared with WT mice (Garcia-Gutierrez et al, 2010). We evaluated acute dose-response effects of cocaine on motor activity, sensitization to cocaine-induced motor effects, CPP, and intravenous cocaine self-administration under both fixed ratio (FR) and progressive ratio (PR) schedules of reinforcement, as well as in vivo microdialysis following acute cocaine administration in both genotypes. In addition, cells expressing $\mathrm{CB}_{2} \mathrm{r}$ were phenotypically characterized using double immunolabeling. Finally, TH and DAT, as well as $\mathrm{CB}_{1} \mathrm{r}$ and $\mu$-opioid receptor gene expression was also measured in the VTA and NAcc, respectively.

\section{MATERIALS AND METHODS}

\section{Animals}

Male $\mathrm{CB}_{2} \mathrm{xP}$ mice were generated in our laboratory, as described previously (Racz et al, 2008), and their corresponding WT littermates (25-35 g bw) were used in all the experiments.

Animals were maintained in a temperature- $\left(21 \pm 1{ }^{\circ} \mathrm{C}\right)$ and humidity- $(65 \pm 10 \%)$ controlled room with a light-dark cycle (lights on from 0800 to 2000 hours) except for the selfadministration studies where a reversed light-dark cycle (lights off from 0800 to 2000 hours) was used. Behavioral tests and animal care were conducted in accordance with the standard ethical guidelines (National Institutes of Health, 1995; European Commission Directive 86/609 EC) and approved by the local ethical committee (CEEA-IMASUPF/UMH). All behavioral experiments were performed under blind conditions.

\section{Drugs}

Cocaine hydrochloride was obtained from The Spanish Agency of Drugs (AGEMED, Madrid, Spain), dissolved in sterile saline and administered $10-40 \mathrm{mg} / \mathrm{kg}$ (i.p.; $0.3 \mathrm{ml}$ ) or $0.5 \mathrm{mg} / \mathrm{kg}$ (i.v.; per infusion).

\section{Acute Motor Effects Induced by Cocaine}

The motor response was evaluated in the open-field test. Mice were individually placed in a transparent square cage $(25 \times 25 \times 25 \mathrm{~cm}$; Urigüen et al, 2004) and the traveled distance was recorded $10 \mathrm{~min}$ after cocaine $(10,20$ and $40 \mathrm{mg} / \mathrm{kg}$ ) or saline administration with a video camera during a period of 20-min and analyzed using the SMART (Spontaneous Motor Activity Recording and Tracking) software system (Panlab, Barcelona, Spain). For details about SMART software see Supplementary Information.

\section{Sensitization to Motor Response Induced by Cocaine}

Mice from both genotypes were selected and divided in three groups receiving saline or cocaine $(10$ or $20 \mathrm{mg} / \mathrm{kg}$, i.p., once daily) for 20 consecutive days. The evaluation of motor sensitization was carried out measuring the traveled distance by mice in the open-field test for $20 \mathrm{~min}$, under baseline conditions, and $10 \mathrm{~min}$ after cocaine/saline administration on days 1,10 , and 20 using the SMART software. 
After the last cocaine administration on day 20, mice remained abstinent for the next 6 days. On day 27, mice were challenged with cocaine (10 and $20 \mathrm{mg} / \mathrm{kg}$, i.p.) or saline and the motor activity was measured again.

\section{Conditioned Place Preference}

WT and $\mathrm{CB}_{2} \mathrm{xP}$ mice were evaluated in a CPP for cocaine (20 mg/kg; i.p.). Details of the features of the apparatus and the procedure used are described in Supplementary Information.

\section{Cocaine Self-Administration}

Details of the features of the apparatus and surgical procedures are described in the Supplementary Information.

Drug self-administration procedure. Four days after surgery, $\mathrm{CB}_{2} \mathrm{xP}$ and WT mice were trained to nose-poke under a FR1 schedule of reinforcement in order to receive cocaine $(0.5 \mathrm{mg} / \mathrm{kg} /$ infusion $)$ for 10 consecutive days, as previously described (Soria et al, 2005). Self-administration sessions starting with a priming injection of the drug $(0.5 \mathrm{mg} / \mathrm{kg} /$ infusion) lasted for $60 \mathrm{~min}$ daily and were conducted 6 days per week. After each session, mice were returned to their home-cages. The number of reinforcers was limited to 50 infusions per session. Each infusion was followed by a 15-s time-out period during which an active nose-poke had no consequence. Stable acquisition of selfadministration behavior was achieved when all of the following conditions were met: (i) $<20 \%$ deviation from the mean of the total number of reinforcers earned in three consecutive sessions ( $80 \%$ stability), (ii) at least $75 \%$ responding on the active hole, and (iii) a minimum of 10 reinforcers earned per session. When stability was acquired, mice were tested on a PR schedule of reinforcement, where the requirement to earn an injection escalated according to the following series: 1-2-3-5-12-18-27-40-60-90-135200-300-450-675-1000 (Soria et al, 2005).

Water-maintained operant behavior. Mice were first deprived of water ( $20 \mathrm{~min}$ of free water was provided daily) for 2 days and this water deprivation regimen was maintained during the whole evaluation of water-maintained operant behavior. Food was available ad libitum during the whole experiment. Two days after starting water deprivation, mice were trained to nose-poke for water under a FR1 schedule of reinforcement, as previously described (Trigo et al, 2007). Responses were maintained by water delivered in $10 \mu \mathrm{l}$ over $10 \mathrm{~s}$, and a time-out period of $20 \mathrm{~s}$ was established after each reinforce. The session was terminated after 100 reinforcers were delivered or after $1 \mathrm{~h}$, whichever occurred first. Mice achieving the acquisition criteria underwent a PR schedule of reinforcement, as reported for drug self-administration.

\section{Immunohistochemistry}

WT and $\mathrm{CB}_{2} \mathrm{xP}$ mice were perfused with $4 \%$ paraformaldehyde, $0.002 \% \mathrm{CaCl}_{2}$ in $0.1 \mathrm{M}$ phosphate buffer (PB; $\mathrm{pH}$
7.3-7.4) for $15 \mathrm{~min}$. Coronal sections ( $60 \mu \mathrm{m}$-thick) were obtained at $0.98-1.70 \mathrm{~mm}$ from bregma, containing the NAcc, and at -2.54 to -2.92 from bregma, containing the VTA and mammillary bodies (MB), using a vibratome. Sections, distributed in eight parallel series, were stored in $0.05 \%$ azide in $\mathrm{PB}$ at $4{ }^{\circ} \mathrm{C}$ and processed for $\mathrm{CB}_{2} \mathrm{r}, \mathrm{D} 1$ and $\mathrm{D} 2$ dopamine receptors (D1Dr and D2Dr, respectively), mature neurons neuronal nuclei (NeuN), and astrocyte's glial fibrillary acidic protein (GFAP) immunohistochemistry using combined double fluorescent labeling. Sections were blocked in 3\% horse serum, $10 \%$ goat serum, and 3\% Triton $\mathrm{X}-100$ in PBS (PB saline), and then incubated overnight at $4^{\circ} \mathrm{C}$ with rabbit anti- $\mathrm{CB}_{2} \mathrm{r}(1: 500$, Cayman Chemical, MI) combined with the following monoclonal antibodies: either anti-NeuN (1:400, Millipore, Temecula, CA) or anti-GFAP (1:1000, Millipore), or anti-D1Dr or anti-D2Dr (both 1:250, Santa Cruz Biotechnology, Santa Cruz, CA). In addition, other set of sections were incubated with rabbit anti-GFAP (1:1000; Sigma-Aldrich, Saint Louis, MO) combined with either mouse anti-D1Dr or anti-D2Dr. All sections were then incubated with horse biotinylated antimouse antibody (1:150, Vector, Burlingame, CA) and avidin-BODIPY FL ( $1 \mathrm{mg} / \mathrm{ml}$, Molecular Probes, Eugene, OR) and with goat rhodamine red-X anti-rabbit $(1: 150$, Molecular Probes). For each combination of two antibodies, the sections containing the NAcc and the VTA-MB from $\mathrm{WT}$ and $\mathrm{CB}_{2} \mathrm{xP}$ mice were processed in parallel. Fluorescent sections were mounted using ProLong Gold (Molecular Probes), studied in a Leica confocal laser fluorescence microscope, and processed using the LCS Lite software.

\section{In Vivo Microdialysis}

Details of the surgical procedure and HPLC conditions are described in the Supplementary Information.

Two days after surgery, animals were habituated to the microdialysis environment overnight. The following morning, probes were perfused with a ringer solution $(\mathrm{NaCl}$ : $148 \mathrm{mM}, \mathrm{KCl}: 2.7 \mathrm{mM} \mathrm{CaCl}_{2}: 1.2 \mathrm{mM}$, and $\mathrm{MgCl}_{2}: 0.8 \mathrm{mM}$, $\mathrm{pH}$ 6.0) at a constant rate of $1 \mu \mathrm{l} / \mathrm{min}$, and a period of $1-\mathrm{h}$ was allowed for stabilization. Four baseline samples were collected in all mice before drug challenge. Subsequently, mice were divided into four treatment groups as follows: Group 1 (WT saline) and group $2\left(\mathrm{CB}_{2} \mathrm{xP}\right.$ saline) received two injections of saline (1 every $80 \mathrm{~min}$ ), whereas group 3 (WT cocaine) and group $4\left(\mathrm{CB}_{2} \mathrm{xP}\right.$ cocaine) received a first injection of saline followed by a second injection of cocaine $(15 \mathrm{mg} / \mathrm{kg}$, i.p), and four samples were collected after each administration. Dialysates $(20 \mu \mathrm{l})$ were injected without any purification into a HPLC system that consisted of a pump linked to an automatic injector (Agilent 1100, Palo Alto, USA), a reverse-phase column (Zorbax SB C18, $5 \mathrm{~mm}, 150 \times 4.6 \mathrm{~mm}$, Agilent Technologies), and a coulometric detector (Coulochem II, ESA, Chelmsford, USA) with a 5011A analytical cell. DA was quantified as previously described (Robledo et al, 2004). At the end of the experiments, mice were killed and the brains were coronally cut using a cryostat. Serial sections $(20 \mu \mathrm{m})$ were stained with cresyl violet (Sigma-Aldrich, Madrid, Spain). Only those mice with correct probe placements were used in the study. 


\section{Gene Expression Analyses Real time PCR}

Mice used in the motor sensitization experiment were killed $150 \mathrm{~min}$ after the cocaine or saline challenge. Brain slices $(500 \mu \mathrm{m})$ were obtained in a cryostat $\left(-10^{\circ} \mathrm{C}\right)$ at different levels (Paxinos and Franklin, 2001) containing the regions of interest and were stored at $-80^{\circ} \mathrm{C}$. From these slices, the regions were dissected out as described elsewhere (Palkovits, 1983). Total RNA was isolated from the brain tissue micropunches using TRI Reagent (Ambion) and subsequently retrotranscribed to cDNA. Quantitative analysis of the relative abundance of $\mathrm{TH}, \mathrm{DAT}$, $\mathrm{CB}_{1} \mathrm{r}$, and $\mu$-opioid receptor gene expressions was performed on the Step One Real Time PCR System (Applied Biosystems) according to the manufacturer's protocol. The reference gene used was $18 \mathrm{~S}$ rRNA, detected using Taqman ribosomal RNA control reagents. Data for each target gene were normalized to the endogenous reference gene and the fold change in target gene mRNA abundance was determined using the $2^{(-\Delta \Delta \mathrm{Ct})}$ method (Livak and Schmittgen, 2001).

\section{Statistical Analyses}

Statistical analyses were performed using Student's $t$-test by comparing two groups and one-, two-, or three-way analyses of variance (ANOVA) when comparing three or more groups. When appropriate, post-hoc individual differences between groups were determined using the Newman-Keuls test. Specific statistical analyses of the microdialysis study are described in Supplementary Information. Differences were considered significant when $P<0.05$. SigmaStat v3.11 and SPSS v17 software were used for statistical analyses.

\section{RESULTS}

Motor Activity in Naïve $\mathrm{CB}_{2} \mathrm{xP}$ and WT Mice: Cocaine Dose-Response Study

No significant differences (NS) were found in motor activity between genotypes, during the 20-min baseline session
(Figure 1a, Student's $t$-test, NS). The dose-response analysis (two-way ANOVA, Figure 1b) showed significant main effects of genotype $\left(\mathrm{F}_{(1,47)}=5.073 ; P<0.05\right)$, treatment $\left(\mathrm{F}_{(3,47)}=88.845 ; P<0.001\right)$, and a significant interaction between genotype and treatment $\left(\mathrm{F}_{(3,47)}=3.134 ; P<0.05\right)$. In both genotypes, cocaine significantly increased motor activity in a dose-dependent manner for 10 and $20 \mathrm{mg} / \mathrm{kg}$ (Student Newman-Keuls, $P<0.05$ ), whereas $40 \mathrm{mg} / \mathrm{kg}$ showed a similar response to $20 \mathrm{mg} / \mathrm{kg}$. However, in $\mathrm{CB}_{2} \mathrm{xP}$ mice the increase in motor activity induced by 10 and $20 \mathrm{mg} / \mathrm{kg}$ of cocaine was significantly lower than the response observed in WT mice (Student Newman-Keuls, $P<0.05$ ).

\section{Sensitization to Motor Response Induced by Cocaine in $\mathrm{CB}_{2} \mathrm{xP}$ and WT Mice: Effect of Challenge with Cocaine After 6 days of Withdrawal}

The sensitization protocol induced a dose-related enhancement in cocaine-induced motor activity, when compared with saline treatment. However, $\mathrm{CB}_{2} \mathrm{xP}$ mice showed significantly less sensitization to cocaine motor effects than WT mice (Figure 2a). Two-way ANOVA with repeated measures showed significant main effects of genotype $\left(\mathrm{F}_{(1,106)}=96.033 ; P<0.001\right)$, treatment $\left(\mathrm{F}_{(2,106)}=742.158\right.$; $P<0.001)$ and time $\left(\mathrm{F}_{(1,106)}=32.206 ; P<0.001\right)$, and significant interactions genotype $\times$ treatment $\left(\mathrm{F}_{(2,106)}=\right.$ $46.845 ; P<0.001)$ and time $\times$ treatment $\left(\mathrm{F}_{(2,106)}=20.449\right.$; $P<0.001)$. No significant interactions were observed between time $\times$ genotype $\left(\mathrm{F}_{(1,106)}=1.413 ; \mathrm{NS}\right)$ or between time $\times$ genotype $\times$ treatment $\left(\mathrm{F}_{(2,106)}=2.199 ; \mathrm{NS}\right)$.

A three-way ANOVA was carried out to analyze the effect of cocaine challenge after 6 days of withdrawal (Figure $2 b$ ). Significant main effects of genotype $\left(\mathrm{F}_{(1,98)}=63.443\right.$; $P<0.001)$, pre-treatment $\left(\mathrm{F}_{(2,98)}=50.936 ; P<0.001\right)$, and challenge dose $\left(\mathrm{F}_{(2,98)}=187.725 ; P<0.001\right)$ were revealed, and significant interactions between genotype $\times$ challenge dose $\left(\mathrm{F}_{(2,98)}=15.902 ; P<0.001\right)$ and pre-treatment $\times$ challenge dose $\left(\mathrm{F}_{(2,98)}=8.906 ; P<0.001\right)$. No significant interactions were observed between genotype $\times$ pretreatment $\left(\mathrm{F}_{(2,98)}=0.926 ; \mathrm{NS}\right)$ or between genotype $\times$ pre-treatment $\times$ challenge dose $\left(\mathrm{F}_{(2,98)}=0.496\right.$; NS). Thus,
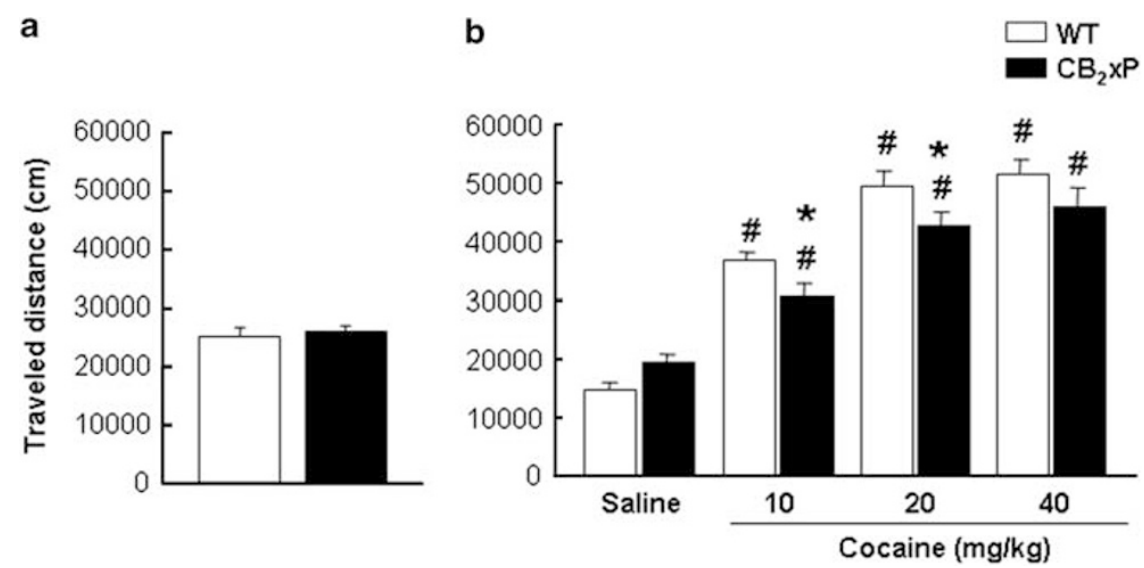

Figure I Motor activity in naive animals and cocaine dose-response study in wild-type (WT) and $\mathrm{CB}_{2} r$ overexpressing $\left(\mathrm{CB}_{2} \times \mathrm{P}\right)$ mice. (a) Columns represent the means and vertical lines + SEM of traveled distance $(\mathrm{cm})$ by WT $(n=20)$ and $\mathrm{CB}_{2} \times P(n=20)$ mice under basal conditions. (b) Columns represent the means and vertical lines + SEM of traveled distance by WT and $\mathrm{CB}_{2} \times P$ mice $(n=6$ per group) in the open-field test during 20 -min, 10 -min after cocaine $(10,20$, and $40 \mathrm{mg} / \mathrm{kg})$ or saline administration. ${ }^{*} P<0.05$ vs WT mice receiving the same treatment. ${ }^{\#} P<0.05$ vs saline-treated mice of similar genotype. 
in saline pre-treated mice both doses of cocaine increased motor behavior compared with the saline challenge, but this effect was significantly lower in the $\mathrm{CB}_{2} \mathrm{xP}$ mice as compared with the WT mice. In cocaine pre-treated mice, the cocaine challenge induced a dose-related increase in traveled distance compared with the saline challenge in WT mice. However, in $\mathrm{CB}_{2} \mathrm{xP}$ mice only the dose of $20 \mathrm{mg} / \mathrm{kg}$ increased locomotion compared with saline. Differences between genotypes were observed and $\mathrm{CB}_{2} \mathrm{xP}$ mice displayed a significantly lower motor response than that observed in WT mice (Figure 2b).

\section{Cocaine Conditioned Place Preference}

During the pre-conditioning period (phase I), no difference was observed in the time spent in the two compartments by both genotypes (Student's $t$-test; NS). These results ruled out the possibility of initial unconditioned preference for either of the two compartments by any of the genotypes. Interestingly, on the test day (phase III), after the
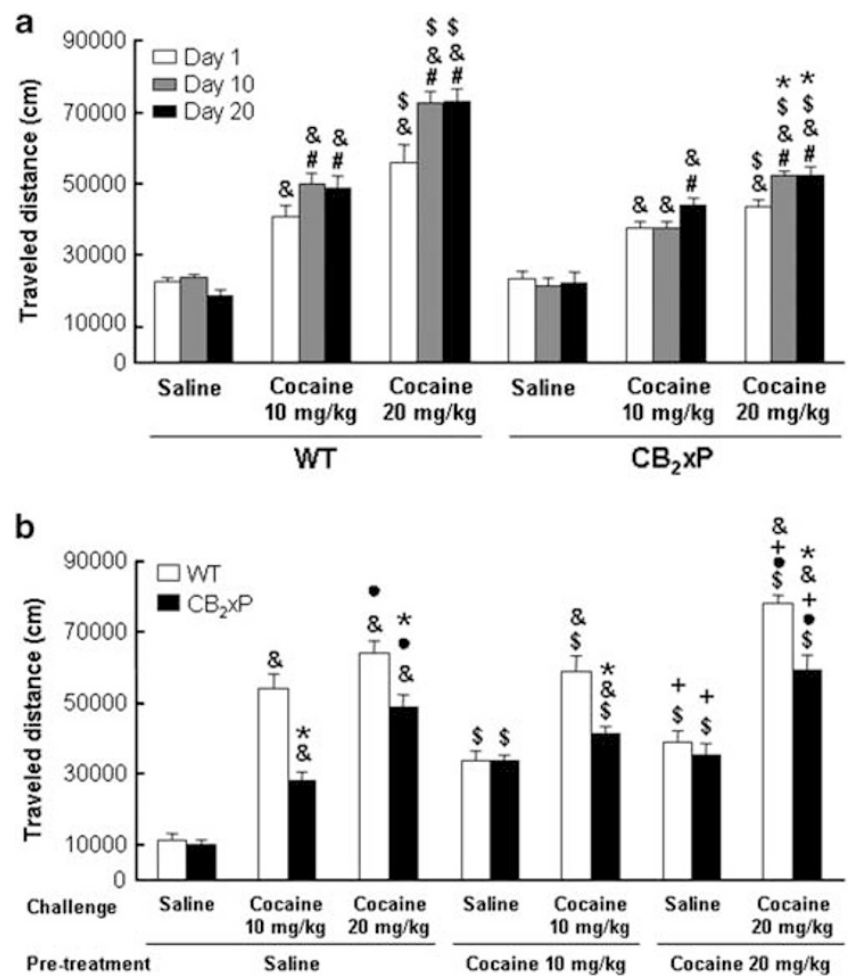

Figure 2 Sensitization to motor response induced by cocaine in wildtype (WT) and $\mathrm{CB}_{2}$ r overexpressing $\left(\mathrm{CB}_{2} \times \mathrm{P}\right)$ mice: Effect of challenge with cocaine after 6 days of withdrawal. Mice received a daily cocaine dose 10 $20 \mathrm{mg} / \mathrm{kg}$ or saline, during 20 days. (a) Columns represent the means and vertical lines + SEM of traveled distance $(\mathrm{cm})$ by mice, on day I, I0, and 20 of cocaine or saline treatment. ${ }^{*} P<0.001$ vs WT mice, ${ }^{\#} P<0.001$ vs day I, ${ }^{\&} P<0.00$ I vs saline, and ${ }^{\$} P<0.001$ vs cocaine $(10 \mathrm{mg} / \mathrm{kg})$. After 6 days of withdrawal from 20 days of cocaine $(10$ or $20 \mathrm{mg} / \mathrm{kg}$ ) or saline pretreatment, both genotypes were challenged with a single dose of cocaine ( 10 or $20 \mathrm{mg} / \mathrm{kg}$ ) or saline; ( $n=7$ mice per group). (b) Columns represent the means and vertical lines + SEM of traveled distance $(\mathrm{cm})$ by mice in the open-field test, after 10 min of cocaine or saline challenge. ${ }^{*} P<0.00$ I vs WT mice, ${ }^{\&} P<0.001$ vs saline challenge, $\bullet P<0.001$ vs cocaine challenge $(10 \mathrm{mg} / \mathrm{kg}),{ }^{\$} P<0.00 \mathrm{I}$ vs saline pre-treatment and, ${ }^{+} P<0.00$ I vs cocaine pre-treatment $(10 \mathrm{mg} / \mathrm{kg})$. conditioning period (phase II), the WT mice did not present a clear CPP for the conditioning compartment, whereas the $\mathrm{CB}_{2} \mathrm{xP}$ mice showed conditioned place aversion. The $\mathrm{CB}_{2} \mathrm{xP}$ mice spent significantly less time $(22 \%)$ in the cocaine-conditioned compartment compared with WT mice (Figure 3, Student's $t$-test, $t=3.707,14 \mathrm{df} ; P<0.05$ ).

\section{Cocaine Self-Administration}

Acquisition of cocaine self-administration in $\mathrm{CB}_{2} \times \mathrm{P}$ and WT mice. $\mathrm{CB}_{2} \mathrm{xP}$ mice self-administer less cocaine than WT mice along the different training sessions (Figure $4 \mathrm{a}$ ). A clear discrimination between the active and the inactive holes was observed for WT mice during the acquisition of operant responding for cocaine $(0.5 \mathrm{mg} / \mathrm{kg} /$ infusion; see Supplementary Information Figure S1A). Mean time to achieve the acquisition criteria for WT mice was $5.0 \pm 0.68$ days, and $100 \%$ of the animals reached the acquisition criteria at day $10 . \mathrm{CB}_{2} \mathrm{xP}$ mice trained to self-administer cocaine started to discriminate between the active and the inactive holes on the fourth training session, and discrimination was maintained from the sixth session until the last session (see Supplementary Information Figure S1B). Oneway ANOVAs were performed comparing genotypes in the active and inactive (see Supplementary Figure S2A) holes for each of the training sessions (see Table 1 for significance values) and comparing active and inactive holes on each of the training sessions for $\mathrm{WT}$ and $\mathrm{CB}_{2} \mathrm{xP}$ mice (see Table 2 for significance values). Mean time to achieve the acquisition criteria for $\mathrm{CB}_{2} \mathrm{xP}$ mice was $7.85 \pm 1.03$ days, and $40 \%$ of the animals reached the acquisition criteria at day 10 . However, the motivation to obtain cocaine in mice achieving the acquisition criteria was similar in both genotypes (Figure 4b). Thus, one-way ANOVA showed no differences between genotypes in the breaking point achieved during the PR schedule of reinforcement. These results suggest a reduction of cocaine reinforcing effects in $\mathrm{CB}_{2} \mathrm{xP}$ mice when compared with WT controls.

Extinction of cocaine self-administration and cueinduced relapse of cocaine-seeking behavior in $\mathrm{CB}_{2} \times \mathrm{P}$ and WT mice. Following PR schedule of reinforcement mice underwent extinction sessions until $<30 \%$ of the

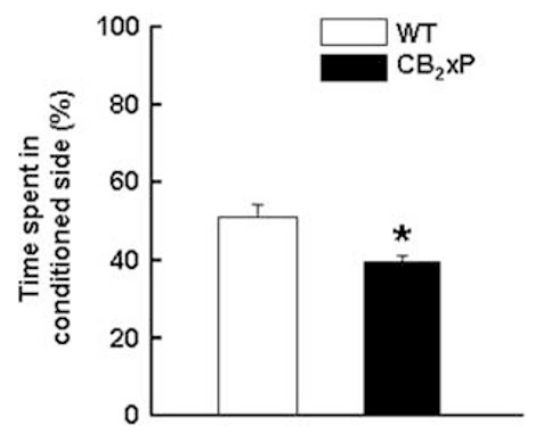

Figure 3 Evaluation of conditioned place preference for cocaine in wildtype $(\mathrm{WT})$ and $\mathrm{CB}_{2}$ r overexpressing $\left(\mathrm{CB}_{2} \times \mathrm{P}\right)$ mice. Columns represent the mean and vertical lines + SEM of time spent in the cocaine conditioned compartment by $\mathrm{WT}(n=8)$ and $\mathrm{CB}_{2} \times \mathrm{P}(n=8)$ mice, expressed as percentage of total time. $* P<0.05$ vs WT mice. 

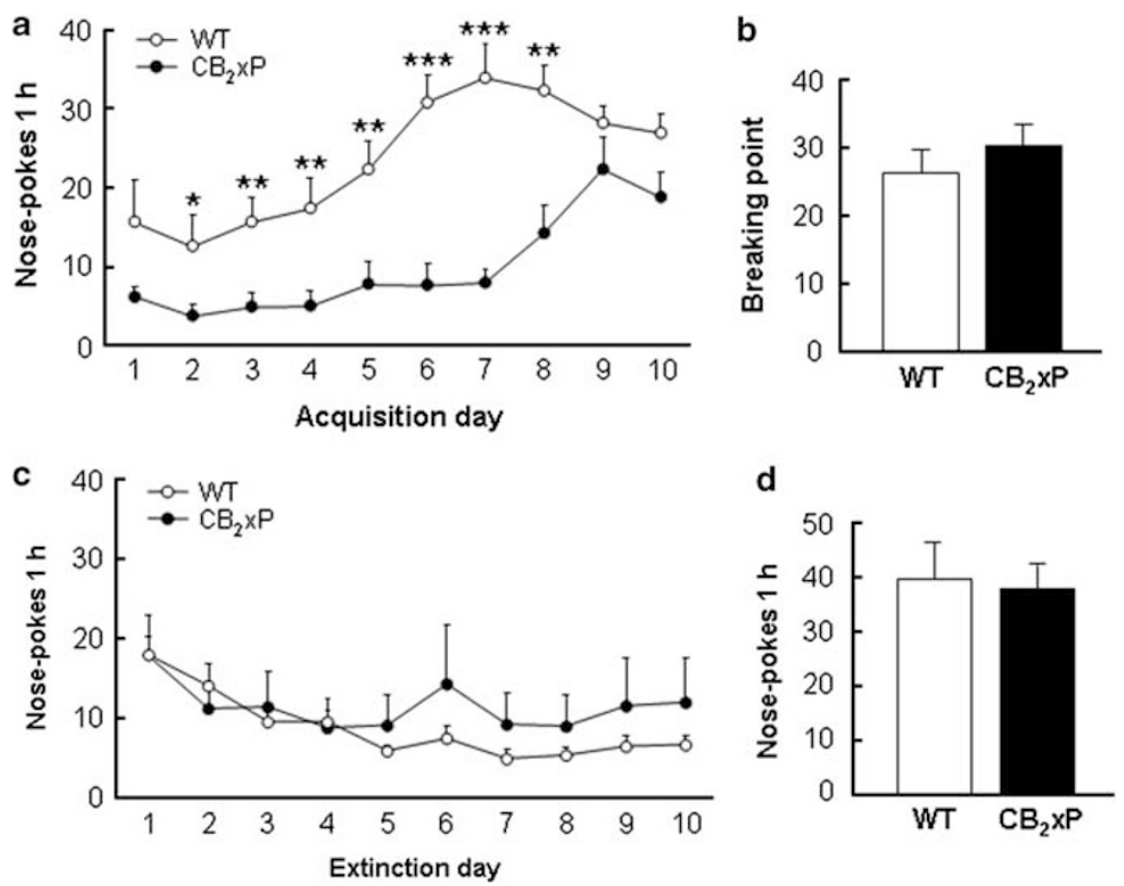

Figure 4 Operant responding for cocaine in wild-type $(\mathrm{WT})$ and $\mathrm{CB}_{2}$ r overexpressing $\left(\mathrm{CB}_{2} \times \mathrm{P}\right)$ mice. (a) Average number of nose-pokes $+\mathrm{SEM}$ in the active hole in WT (empty circles) and $\mathrm{CB}_{2} \times \mathrm{P}$ (filled circles) mice in I-h sessions during 10 days of training with cocaine $(0.5 \mathrm{mg} / \mathrm{kg} / \mathrm{infusion}) ; \mathrm{WT}$ ( $\left.n=8\right)$, $\mathrm{CB}_{2} \times P(n=10)$. (b) Breaking point achieved by WT (white bar) and $\mathrm{CB}_{2} \times P$ (black bar) mice under a progressive ratio schedule of reinforcement; WT $(n=8), C_{2} \times P(n=7)$. (c) Average number of nose-pokes + SEM during the initial 10 sessions of extinction in the active hole in both WT (empty circles) and $\mathrm{CB}_{2} \times \mathrm{P}$ (filled circles) mice. (d) Responding in the active hole during cue-induced relapse of cocaine-seeking behavior tests in WT (white bar) and $\mathrm{CB}_{2} \times \mathrm{P}$ (black bar) mice; WT $(n=8), \mathrm{CB}_{2} \times \mathrm{P}(n=7)$. ${ }^{*} P<0.05$, *** $P<0.0$ I, **** $P<0.00 \mathrm{I}, \mathrm{CB}_{2} \times \mathrm{P}$ mice vs WT mice.

Table I One-Way ANOVA for Response in the Active and Inactive Holes in WT vs $\mathrm{CB}_{2} \times \mathrm{P}$ Mice Self-Administering Cocaine

\begin{tabular}{|c|c|c|c|c|}
\hline & \multicolumn{2}{|c|}{ Active } & \multicolumn{2}{|c|}{ Inactive } \\
\hline & $\mathbf{F}$ & $P$ & $\mathbf{F}$ & $P$ \\
\hline Day I & $F_{(1,17)}=3.300$ & NS & $F_{(1,17)}=5.909$ & 0.05 \\
\hline Day 2 & $F_{(1,17)}=5.185$ & 0.05 & $F_{(1,17)}=0.011$ & NS \\
\hline Day 3 & $F_{(1,17)}=8.834$ & 0.01 & $F_{(1,17)}=0.144$ & NS \\
\hline Day 4 & $F_{(1,17)}=8.801$ & 0.01 & $F_{(1,17)}=7.262$ & 0.05 \\
\hline Day 5 & $F_{(1,16)}=9.128$ & 0.01 & $F_{(1,16)}=7.257$ & 0.05 \\
\hline Day 6 & $F_{(1,16)}=29.269$ & 0.001 & $F_{(1,16)}=2.647$ & NS \\
\hline Day 7 & $F_{(1,17)}=37.142$ & 0.001 & $F_{(1,17)}=0.577$ & NS \\
\hline Day 8 & $F_{(1,17)}=13.556$ & 0.01 & $F_{(1,17)}=1.549$ & NS \\
\hline Day 9 & $F_{(1,16)}=1.451$ & NS & $F_{(1,16)}=2.868$ & NS \\
\hline Day 10 & $F_{(1,17)}=3.941$ & NS & $F_{(1.17)}=0.152$ & NS \\
\hline
\end{tabular}

mean response on the active hole (during acquisition) was observed (Figure 4c; see Supplementary Figure S2B for operant response in the inactive hole). Mice achieving the criteria for extinction underwent a reinstatement session evaluating cue-induced relapse to cocaine-seeking behavior (Figure 4d). No apparent differences between genotypes in the extinction process or in the capacity of cue to induce reinstatement of cocaine-seeking behavior were observed (see ANOVAs analyses in Supplementary Information).
Table 2 One-way ANOVAs for Active vs Inactive Hole Discrimination in WT and $\mathrm{CB}_{2} \times \mathrm{P}$ Mice Self-Administering Cocaine

\begin{tabular}{|c|c|c|c|c|}
\hline & \multicolumn{2}{|c|}{ Wild type } & \multicolumn{2}{|c|}{$\mathrm{CB}_{2} \times \mathrm{P}$} \\
\hline & $\mathbf{F}$ & $P$ & $\mathbf{F}$ & $P$ \\
\hline Day I & $F_{(1,15)}=1.454$ & NS & $F_{(1,19)}=3.477$ & NS \\
\hline Day 2 & $F_{(1,15)}=6.518$ & 0.05 & $F_{(1,19)}=1.102$ & NS \\
\hline Day 3 & $F_{(1,15)}=14.879$ & 0.01 & $F_{(1,19)}=1.57 \mid$ & NS \\
\hline Day 4 & $F_{(1,15)}=10.155$ & 0.01 & $F_{(1,19)}=5.403$ & 0.05 \\
\hline Day 5 & $F_{(1,15)}=22.105$ & 0.001 & $F_{(1,17)}=.085$ & NS \\
\hline Day 6 & $F_{(1,15)}=68.814$ & 0.001 & $F_{(1,17)}=5.686$ & 0.05 \\
\hline Day 7 & $F_{(1,15)}=54.663$ & 0.001 & $F_{(1,19)}=12.877$ & 0.01 \\
\hline Day 8 & $F_{(1,15)}=85.751$ & 0.001 & $F_{(1,19)}=10.004$ & 0.01 \\
\hline Day 9 & $F_{(1,15)}=126.989$ & 0.001 & $F_{(1,17)}=26.302$ & 0.001 \\
\hline Day 10 & $F_{(1,15)}=100.55 \mid$ & 0.001 & $F_{(1.19)}=32.591$ & 0.001 \\
\hline
\end{tabular}

Water maintained self-administration in $\mathrm{CB}_{2} \times P$ and WT mice. Additional $\mathrm{CB}_{2} \mathrm{xP}$ and WT mice were trained to self-administer water under a FR1 schedule of reinforcement (Figure 5a). WT animals started to discriminate between the active and the inactive holes from the third training session (data not shown) and the discrimination was maintained during the next seven sessions. The stability criteria were achieved by $86 \%$ of the animals tested and the mean time required to reach it at this group was $4.83 \pm 0.90$ 


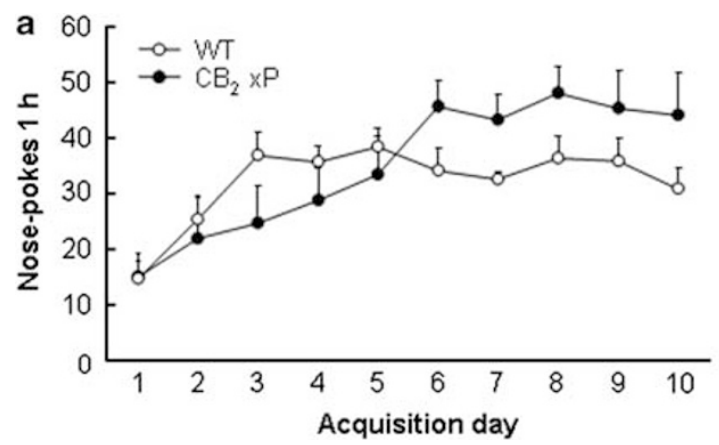

b

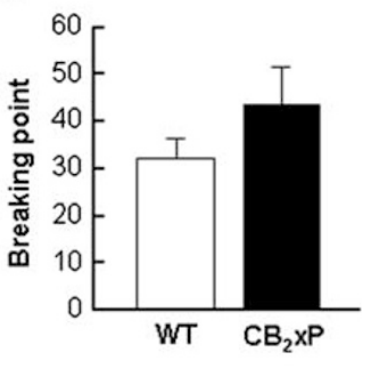

Figure 5 Acquisition of operant responding for water in wild-type (WT) and $\mathrm{CB}_{2}$ r overexpressing $\left(\mathrm{CB}_{2} \times \mathrm{P}\right)$ mice. (a) Average number of nose-pokes + SEM in the active hole in both WT (empty circles) and $\mathrm{CB}_{2} \times P$ (filled circles) mice in I-h sessions during I 0 days of training with water under a fixed ratio I (FRI) schedule of reinforcement ( $10 \mu \mathrm{l}$ of water in $10 \mathrm{~s}$ ); WT $(n=7), \mathrm{CB}_{2} \times \mathrm{P}(n=8)$. (b) Breaking point achieved by WT (white bar) and $C B_{2} \times \mathrm{P}$ (black bar) mice under a progressive ratio schedule of reinforcement; $\mathrm{WT}(n=6), \mathrm{CB}_{2} \times \mathrm{P}(n=8)$.

days. $\mathrm{CB}_{2} \mathrm{xP}$ mice also showed discrimination from the third until the last training session. In this group, the stability criterion was achieved by all the animals tested and the mean time required to reach it was of $4.12 \pm 0.81$ days. Oneway ANOVA showed no significant differences between $\mathrm{CB}_{2} \mathrm{xP}$ and WT control mice in the number of drinks selfadministrated on any training day (see Table 3 for significance values and Supplementary Figure S2C).

In order to evaluate whether $\mathrm{WT}$ and $\mathrm{CB}_{2} \mathrm{xP}$ presented differences in the motivation to obtain water, mice achieving the acquisition criteria underwent a PR schedule of reinforcement. No differences between genotypes were observed in the breaking point achieved under the PR schedule (Figure 5b). These results show that the reinforcing effects of the natural reinforcer (water) were not modified in $\mathrm{CB}_{2} \mathrm{xP}$ mice, and the capacity of these mice to acquire an operant responding also remained unaltered.

\section{Phenotypical Characterization of NAcc and VTA Cells}

In WT and $\mathrm{CB}_{2} \mathrm{xP}$ mice, cells double immunolabeled with $\mathrm{CB}_{2} \mathrm{r}$-NeuN (Figure 6a-f) and $\mathrm{CB}_{2} \mathrm{r}$-GFAP (Figure $6 \mathrm{~g}-\mathrm{l}$ ) antibodies were seen in several regions of the mice brain, and in particular in the NAcc and VTA, which indicates that both neurons and astrocytes are $\mathrm{CB}_{2} \mathrm{r}$ immunoreactive (i.r.) in these areas. All neurons were CB2r i.r. but a few of GFAP i.r. astrocytes were not labeled with $\mathrm{CB}_{2} \mathrm{r}$ antibodies. $\mathrm{CB}_{2} \mathrm{r}$ immunolabeling was found in the soma of the neuron and in the surrounding neuropile (Figure 6a-f), whereas it was observed in the soma and processes of the astrocytes (Figure 6g-1).

D1Dr i.r. cells were seen in several brain regions in both WT and $\mathrm{CB}_{2} \mathrm{xP}$ mice. However, no D1Dr i.r. cells were seen in the NAcc and VTA in WT or in $\mathrm{CB}_{2} \mathrm{xP}$ mice (Figure $7 \mathrm{a}-\mathrm{c}$ ). For instance, in the hippocampal dentate gyrus (Figure $7 \mathrm{~g}-$ i), some cells were D1Dr i.r. and a fraction of these were also $\mathrm{CB}_{2}$ r i.r. D2Dr i.r. cells were seen in the NAcc and VTA, which were also $\mathrm{CB}_{2} \mathrm{r}$ i.r. (Figure $7 \mathrm{~d}-\mathrm{f}$ ). However, immunolabeling of these cells in the NAcc and VTA (Figure 7a-f and Supplementary Figure S3) was weaker than that of cells located in other brain areas such as the cortex and $\mathrm{MB}$
Table 3 One-way ANOVAs for Active vs Inactive Hole Discrimination in WT and $\mathrm{CB}_{2} \times \mathrm{P}$ Mice Self-Administering Water

\begin{tabular}{|c|c|c|c|c|}
\hline & \multicolumn{2}{|c|}{ Wild type } & \multicolumn{2}{|c|}{$\mathrm{CB}_{2} \times \mathrm{P}$} \\
\hline & $\mathbf{F}$ & $P$ & $\mathbf{F}$ & $P$ \\
\hline Day I & $F_{(1,13)}=0.399$ & NS & $F_{(1,15)}=0.158$ & NS \\
\hline Day 2 & $F_{(1,13)}=2.605$ & NS & $F_{(1,15)}=4.304$ & NS \\
\hline Day 3 & $F_{(1,13)}=18.387$ & 0.01 & $F_{(I, 15)}=8.207$ & 0.05 \\
\hline Day 4 & $F_{(1,13)}=8.343$ & 0.05 & $F_{(1,15)}=18.919$ & 0.01 \\
\hline Day 5 & $F_{(1,13)}=27.465$ & 0.001 & $F_{(1,15)}=20.743$ & 0.001 \\
\hline Day 6 & $F_{(1,13)}=44.865$ & 0.001 & $F_{(1,15)}=75.585$ & 0.001 \\
\hline Day 7 & $F_{(I, 11)}=58.24 I$ & 0.001 & $F_{(1,15)}=85.760$ & 0.001 \\
\hline Day 8 & $F_{(1,13)}=28.969$ & 0.001 & $F_{(1,15)}=91.621$ & 0.001 \\
\hline Day 9 & $F_{(1,13)}=31.640$ & 0.001 & $F_{(1,15)}=42.744$ & 0.001 \\
\hline Day 10 & $F_{(1,13)}=47.834$ & 0.001 & $F_{(1.13)}=29.544$ & 0.001 \\
\hline
\end{tabular}

(Figure 7j-1). In all cases, both D1Dr i.r. and D2Dr i.r. cells remained unlabeled with anti-GFAP antibodies suggesting that they were neurons (Supplementary Figure S3).

\section{In Vivo Microdialysis}

Histological analysis of the brains showed that all the animals included in the experiment had microdialysis probes placed correctly in the NAcc (between $+1.10 \mathrm{~mm}$. and $+1.78 \mathrm{~mm}$ anterior to bregma; Figure $8 \mathrm{a}$ ).

No significant differences in basal extracellular DA levels in the NAcc were observed between genotypes (mean of four baseline samples: WT: $4.32 \pm 1.04 \mathrm{pg} / 20 \mu \mathrm{l} ; \mathrm{CB}_{2} \mathrm{xP}$ : $4.94 \pm 0.94 \mathrm{pg} / 20 \mu \mathrm{l}$; Figure $8 \mathrm{~b}$ ). Two-way repeated measures ANOVA revealed a significant main effect of time $\left(\mathrm{F}_{(3,72)}=2.910 ; P<0.05\right)$, but no significant effect of the treatment group was observed $\left(\mathrm{F}_{(3,24)}=1.627\right.$; NS), and no significant interaction between factors $\left(\mathrm{F}_{(9,72)}=1.848\right.$; NS) was found. Following saline administration, no significant differences in DA outflow were observed between treatment groups. Two-way repeated measures ANOVA revealed 

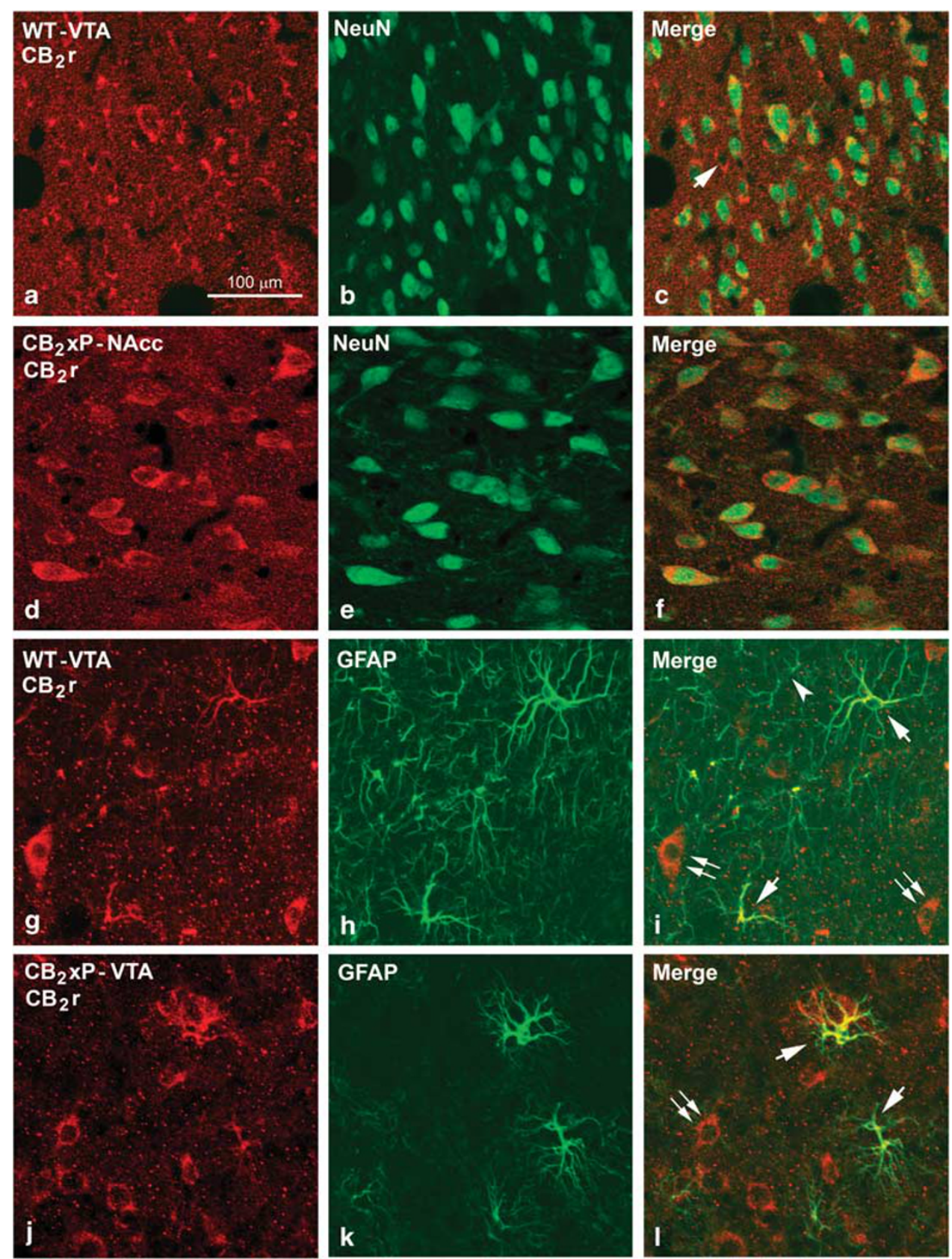

Figure 6 Immunolabeling for $\mathrm{CB}_{2}$ receptors $\left(\mathrm{CB}_{2} r\right)$ and neuronal nuclei (NeuN) in the ventral tegmental area (VTA) and the nucleus accumbens (NAcc) and for $\mathrm{CB}_{2} r$ and glial fibrillary acidic protein (GFAP) in the VTA of wild-type (WT) and $\mathrm{CB}_{2}$ r overexpressing $\left(\mathrm{CB}_{2} \times \mathrm{P}\right)$ mice. Confocal photomicrographs showing immunolabeling for $\mathrm{CB}_{2} r$ (red cells in (a) and (d)) and NeuN (green cells in (b) and (e)) in the VTA of WT and the NAcc of CB $\times$ PP mice. Double labeling (yellow cells in (c) and (f)) both in the VTA and the NAcc indicates that most of the $\mathrm{CB}_{2} r$ immunoreactive (i.r.) cells are neurons. $A \mathrm{CB}_{2} r$ cell not labeled for NeuN is shown in (c) (arrow). ( $\mathrm{g}-\mathrm{l})$ Immunolabeling for $\mathrm{CB}_{2} r$ (red cells in (g) and (j)) and GFAP (green cells in (h) and (k)) in the VTA of WT and $\mathrm{CB}_{2} \times \mathrm{P}$ mice. Double labeling (yellow cells in (i) and (I)) shows that most of the GFAP i.r. astrocytes are also immunolabeled for $\mathrm{CB}_{2} r($ arrows in (i) and (I)). GFAP i.r. astrocytes not $\mathrm{CB}_{2}$ r i.r. can be rarely seen (arrow head). $\mathrm{CB}_{2} r$ immunolabeled cells, most probably neurons, are showed in (i) and (I) (double arrow). Same scale for (b-l).

non-significant main effects of time $\left(\mathrm{F}_{(3,72)}=1.098 ; \mathrm{NS}\right)$ or treatment group $\left(\mathrm{F}_{(3,24)}=0.039\right.$; NS), and no interaction between factors $\left(\mathrm{F}_{(9,72)}=1.942\right.$; NS; Figure $\left.8 \mathrm{~b}\right)$. Following the cocaine challenge, two-way repeated measures ANOVA revealed significant main effects of time $\left(\mathrm{F}_{(3,72)}=16.953\right.$; $P<0.001)$ and treatment group $\left(\mathrm{F}_{(3,24)}=6.639 ; P<0.01\right)$, and a significant interaction between factors $\left(\mathrm{F}_{(9,72)}=6.021\right.$;
$P<0.001)$. Subsequent post-hoc tests revealed that the challenge administration of cocaine at $15 \mathrm{mg} / \mathrm{kg}$ increased DA levels in the NAcc compare with saline administration in WT and $\mathrm{CB}_{2} \mathrm{xP}$ mice (WT: $P<0.05 ; \mathrm{CB}_{2} \mathrm{xP}: P<0.01$ ), but this increase was not significantly different between genotypes (WT cocaine vs $\mathrm{CB}_{2} \mathrm{xP}$ cocaine: $P>0.05$; Figure $8 b)$. 

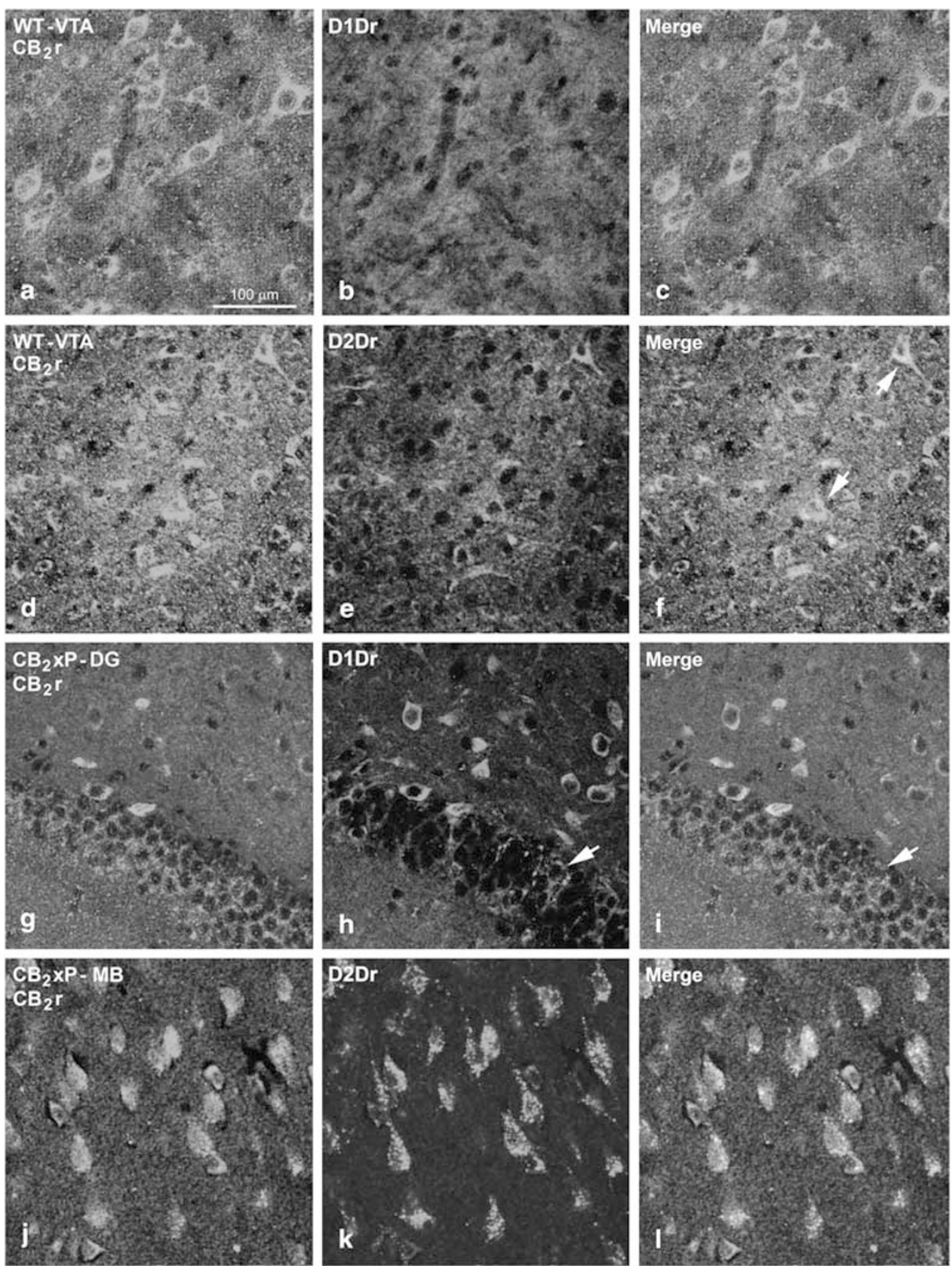

Figure 7 Immunolabeling for $\mathrm{CB}_{2}$ receptors $\left(\mathrm{CB}_{2} r\right)$, DI and D2 dopamine receptors (DIDr and D2Dr, respectively) in wild-type (WT) and $C B_{2} r$ overexpressing $\left(\mathrm{CB}_{2} \times \mathrm{P}\right)$ mice. Confocal photomicrographs showing immunolabeling for $\mathrm{CB}_{2} r$ (red cells in (a), (d), (g) and, (j)), and DIDr and D2Dr (green cells in (b), (e), (h) and, (k)) in the ventral tegmental area (VTA) of WT mice (a-f), hippocampal dentate gyrus (DG; g-i) and mammillary bodies (MB; $j-l)$ of $\mathrm{CB}_{2} \times \mathrm{P}$ mice. Double labeling (yellow cells) is shown in (c), ( $\mathrm{f}$, (i), and (I). In the VTA and the NAcc no DIDr immunoreactive (i.r.) cells were seen, but they were more numerous in other brain areas. Several DIDr i.r. neurons in the granular layer (arrow) and hilus of the dentate gyrus of the hippocampus are shown; some of them are also $\mathrm{CB}_{2} r$ i.r. (yellow labeling in (i)). Neurons double labeled for $\mathrm{CB}_{2} r$ and D2Dr in the MB are shown (I). Note that most of the D2Dr i.r. are also labeled for $\mathrm{CB}_{2}$ r. Same scale for $(b-1)$.

\section{Changes in TH and DAT Gene Expression Induced by Cocaine in the VTA of $\mathrm{CB}_{2} \mathrm{xP}$ and WT Mice}

The results showed increased baseline TH gene expression in the VTA of $\mathrm{CB}_{2} \mathrm{xP}$ compared with WT mice (Figure 9a, Student's $t$-test, $t=-3.551,12 \mathrm{df} ; P<0.05)$. After the saline or cocaine challenge, the three-way ANOVA revealed significant main effects of genotype $\left(\mathrm{F}_{(1,70)}=17.760\right.$;
$P<0.001)$, pre-treatment $\left(\mathrm{F}_{(2,70)}=12.716 ; P<0.001\right)$, and challenge dose $\left(\mathrm{F}_{(2,70)}=106.267 ; P<0.001 ;\right.$ Figure $\left.9 \mathrm{~b}\right)$. Significant interactions between genotype $\times$ pre-treatment $\left(\mathrm{F}_{(2,70)}=15.142 ; P<0.001\right)$, genotype $\times$ challenge dose $\left(\mathrm{F}_{(2,70)}=18.430 ; P<0.001\right)$, pre-treatment $\times$ challenge dose $\left(\mathrm{F}_{(2,70)}=5.574 ; P<0.01\right)$, and genotype $\times$ pre-treatment $\times$ challenge dose $\left(\mathrm{F}_{(2,70)}=3.882 ; P<0.05\right)$ were found. $\mathrm{CB}_{2} \mathrm{xP}$ mice pre-treated with saline showed increased TH gene 
a
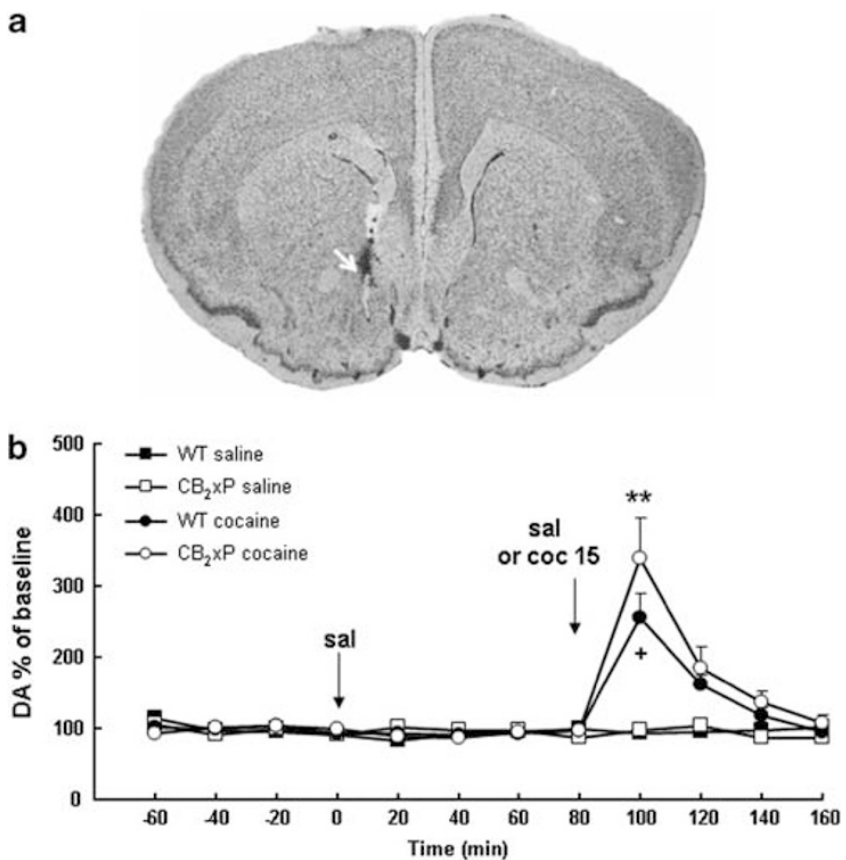

Figure 8 Microdialysis data for wild-type (WT) and $\mathrm{CB}_{2}$ r overexpressing $\left(\mathrm{CB}_{2} \times \mathrm{P}\right)$ mice. (a) A coronal section of the brain of a representative mouse stained with cresyl violet (magnification: $\times 2.0$ ) showing the position of the microdialysis probe in the NAcc. (b) Dopamine (DA) outflow in the NAcc (\% of baseline + SEM) during $240 \mathrm{~min}$ before and after drug challenge (arrows) in four treatment groups: Group I (WT saline (sal)) and group 2 ( $\mathrm{CB}_{2} \times \mathrm{P}$ saline) received two injections of saline (one every $80 \mathrm{~min}$ ), group 3 (WT cocaine (COC)) and group $4\left(\mathrm{CB}_{2} \times \mathrm{P}\right.$ cocaine) received a first injection of saline followed by a second injection of cocaine ( $15 \mathrm{mg} / \mathrm{kg}$, i.p), and four dialysates $(20 \mu \mathrm{l})$ were collected after each administration. $* * P<0.0$ ( $\mathrm{CB}_{2} \times \mathrm{P}$ cocaine vs $\mathrm{CB}_{2} \times \mathrm{P}$ saline), ${ }^{+} \mathrm{P}<0.05$ (WT cocaine vs $\mathrm{WT}$ saline).

expression compared with WT mice, supporting baseline differences between the two genotypes.

The effect of both cocaine pre-treatment and challenge reduced $\mathrm{TH}$ gene expression in $\mathrm{CB}_{2} \mathrm{xP}$ and $\mathrm{WT}$ mice $(P<0.001)$. In animals pre-treated with $20 \mathrm{mg} / \mathrm{kg}$ of cocaine there was significantly reduced $\mathrm{TH}$ gene expression compared with those pre-treated with $10 \mathrm{mg} / \mathrm{kg}$ of cocaine or saline $(P<0.05)$. On the other hand, cocaine challenge induced a dose-related significant reduction of TH gene expression compared with saline challenged mice $(P<0.05)$. In contrast, $\mathrm{CB}_{2} \mathrm{xP}$ mice pre-treated with $20 \mathrm{mg} / \mathrm{kg}$ of cocaine and challenged with saline exhibited significantly increased TH gene expression compared with WT mice receiving the same treatment. This difference was not observed with the cocaine challenge $(20 \mathrm{mg} / \mathrm{kg})$.

Baseline DAT gene expression was significantly increased in $\mathrm{CB}_{2} \mathrm{xP}$ compared with WT mice (Figure 9c, Student's $t$-test, $t=-2.967,11 \mathrm{df} ; P<0.05)$. The three-way ANOVA revealed significant changes in DAT gene expression after cocaine or saline challenge due to genotype $\left(\mathrm{F}_{(1,70)}=79.621\right.$; $P<0.001)$, pre-treatment $\left(\mathrm{F}_{(2,70)}=10.127 ; P<0.001\right)$, and challenge dose $\left(F_{(2,70)}=5.875 ; P<0.005\right.$; Figure $\left.9 d\right)$. Significant interaction between genotype $\times$ pre-treatment $\left(\mathrm{F}_{(2,70)}=4.965 ; P<0.05\right)$ was found, whereas genotype $\times$ challenge dose $\left(\mathrm{F}_{(2,70)}=1.744 ; \mathrm{NS}\right)$, pre-treatment $\times$ challenge dose $\left(\mathrm{F}_{(2,70)}=0.889\right.$; NS), and genotype $\times$ pretreatment $\times$ challenge dose $\left(\mathrm{F}_{(2,70)}=1.709\right.$; NS) were not significant. Regarding genotype, these results confirmed baseline differences between $\mathrm{CB}_{2} \mathrm{xP}$ and WT mice. The effect of cocaine pre-treatment $(10$ and $20 \mathrm{mg} / \mathrm{kg}$ reduced gene expression of DAT compared with saline pretreatment in WT mice $(P<0.05)$. Moreover, the decrease of DAT gene expression induced by cocaine challenge in cocaine pre-treated mice was $50 \%$ lower in $\mathrm{CB}_{2} \times \mathrm{P}$ compared with WT mice.

\section{Changes in $\mu$-Opioid and $\mathrm{CB}_{1} \mathrm{r}$ Gene Expression Induced by Cocaine in the NAcc of $\mathrm{CB}_{2} \mathrm{xP}$ and WT Mice}

$\mathrm{CB}_{2} \mathrm{xP}$ mice presented decreased baseline $\mu$-opioid receptor gene expression compared with WT mice (Figure 10a, Student's $t$-test, $t=3.005,13 \mathrm{df} ; P<0.001)$. The three-way ANOVA revealed significant changes in $\mu$-opioid receptor gene expression after cocaine or saline challenge due to genotype $\quad\left(\mathrm{F}_{(1,70)}=12.930 ; \quad P<0.005\right), \quad$ pre-treatment $\left(\mathrm{F}_{(2,70)}=44.926 ; \quad P<0.001\right), \quad$ and challenge dose $\left(\mathrm{F}_{(2,70)}=19.386 ; P<0.001\right.$; Figure $\left.10 \mathrm{~b}\right)$. Significant interactions between pre-treatment $\times$ challenge dose $\left(\mathrm{F}_{(2,70)}=39.075 ; P<0.001\right)$ and genotype $\times$ pre-treatment $\times$ challenge dose $\left(\mathrm{F}_{(2,70)}=3.788 ; P<0.05\right)$ were found, whereas genotype $\times$ pre-treatment $\left(\mathrm{F}_{(2,70)}=0.320 ; \mathrm{NS}\right)$ and genotype $\times$ challenge dose $\left(\mathrm{F}_{(2,70)}=1.719\right.$; NS) were not significant. Regarding genotype, these results confirmed baseline differences between $\mathrm{CB}_{2} \mathrm{xP}$ and WT mice. Cocaine pre-treatment reduced $\mu$-opioid receptor gene expression in $\mathrm{CB}_{2} \mathrm{xP}$ and WT mice $(P<0.001)$. Animals pre-treated with 10 and $20 \mathrm{mg} / \mathrm{kg}$ of cocaine presented a significant reduction compared with those pre-treated with saline $(P<0.05)$. On the other hand, depending on pre-treatment received, cocaine challenge $(20 \mathrm{mg} / \mathrm{kg})$ induced a different effect on $\mu$-opioid receptor gene expression compared with cocaine $(10 \mathrm{mg} / \mathrm{kg})$ and saline challenged mice (Figure $10 \mathrm{~b})$. Thus, in saline pre-treated mice, a cocaine challenge $(20 \mathrm{mg} /$ $\mathrm{kg}$ ) significantly increased $\mu$-opioid receptor gene expression $(P<0.05)$. In contrast, the challenge with cocaine significantly decreased $\mu$-opioid receptor gene expression $(P<0.05)$ in mice pre-treated with cocaine.

On the other hand, under baseline conditions no differences were found in $\mathrm{CB}_{1} \mathrm{r}$ gene expression between $\mathrm{CB}_{2} \mathrm{xP}$ and WT mice (Figure 10c, Student's $t$-test; NS). The three-way ANOVA revealed significant changes in $\mathrm{CB}_{1} \mathrm{r}$ gene expression after cocaine or saline challenge due to pre-treatment $\left(\mathrm{F}_{(2,70)}=38.303 ; P<0.001\right)$ and challenge dose $\quad\left(\mathrm{F}_{(2,70)}=13.423 ; \quad P<0.001\right)$, whereas genotype $\left(\mathrm{F}_{(1,70)}=0.271\right.$; NS) was not significant (Figure 10d). Significant interactions between genotype $\times$ pre-treatment $\left(\mathrm{F}_{(2,70)}=19.719 ; P<0.001\right)$, genotype $\times$ challenge dose $\left(\mathrm{F}_{(2,70)}=6.526 ; P<0.005\right)$, pre-treatment $\times$ challenge dose $\left(\mathrm{F}_{(2,70)}=28.894 ; P<0.001\right)$, and genotype $\times$ pre-treatment $x$ challenge dose $\left(\mathrm{F}_{(2,70)}=7.232 ; P<0.005\right)$ were found. Regarding genotype, these results confirmed the lack of significant differences in baseline $\mathrm{CB}_{1} \mathrm{r}$ gene expression between $\mathrm{CB}_{2} \mathrm{xP}$ and $\mathrm{WT}$ mice. The effect of both cocaine pre-treatment and challenge reduced the expression of $\mathrm{CB}_{1} \mathrm{r}$ gene in $\mathrm{CB}_{2} \mathrm{xP}$ and WT mice $(P<0.001)$. Thus, animals pretreated with cocaine presented a dose-related significant reduction compared with those pre-treated with saline $(P<0.05)$. On the other hand, cocaine challenge (10 and $20 \mathrm{mg} / \mathrm{kg}$ ) induced a significant reduction of $\mathrm{CB}_{1} \mathrm{r}$ gene 
a
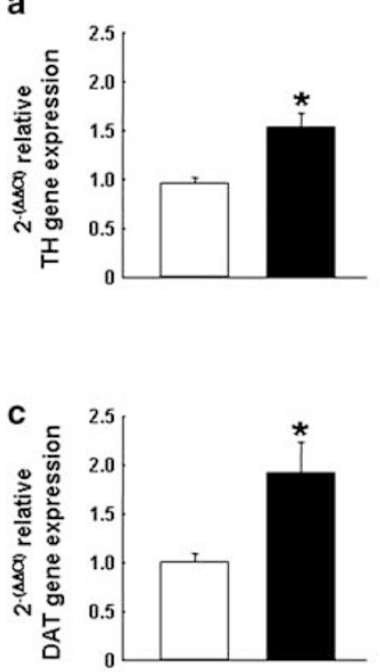

b

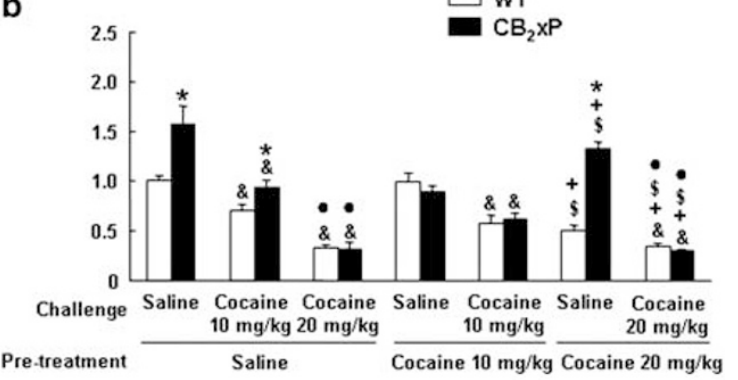

d

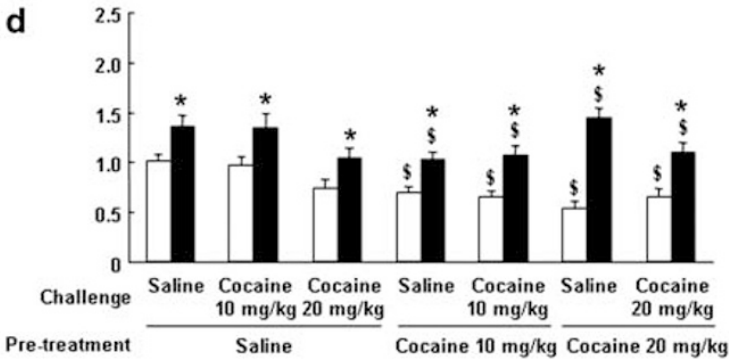

Figure 9 Changes in tyrosine hydroxylase (TH) and DA transporter (DAT) gene expression induced by cocaine in the ventral tegmental area (VTA) of $\mathrm{CB}_{2}$ r overexpressing $\left(\mathrm{CB}_{2} \times P\right)$ and wild-type $(\mathrm{WT})$ mice. (a, c) Columns represent the means and vertical lines + SEM of 2 ${ }^{(-\Delta \Delta C t)}$ of relative TH and DAT gene expression, respectively, in WT $(n=6)$ and $\mathrm{CB}_{2} \times \mathrm{P}(n=6)$ mice measured in the VTA under baseline conditions. $(b, d) W T$ and $C B_{2} \times P$ mice $(n=6$ per group) received a challenge of saline or cocaine $(10-20 \mathrm{mg} / \mathrm{kg}$ ) after 6 days of withdrawal from 20 days of pre-treatment with saline or cocaine ( $10-20 \mathrm{mg} /$ $\mathrm{kg}$ ). Columns represent the means and vertical lines + SEM of $2^{(-\Delta \Delta \mathrm{Ct})}$ of relative TH and DAT gene expression in WT and $\mathrm{CB}_{2} \times \mathrm{P}$ mice challenged with saline or cocaine. ${ }^{*} P<0.001$ vs $W T$, ${ }^{\circledR} P<0.05$ vs saline challenge, $\bullet P<0.05$ vs cocaine challenge $(10 \mathrm{mg} / \mathrm{kg}),{ }^{\$} P<0.05$ vs saline pre-treatment and, ${ }^{+} P<0.05$ vs cocaine pre-treatment $(10 \mathrm{mg} / \mathrm{kg})$.

a
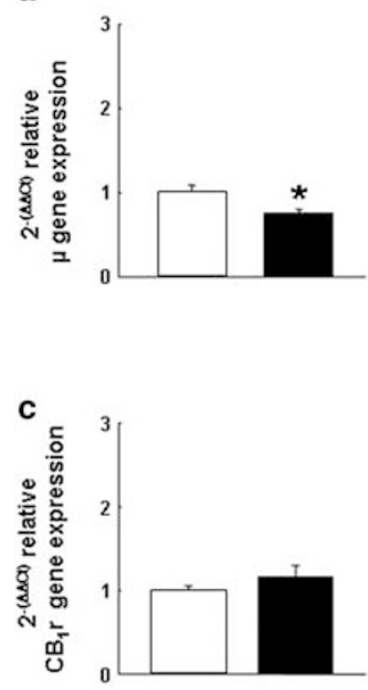

b

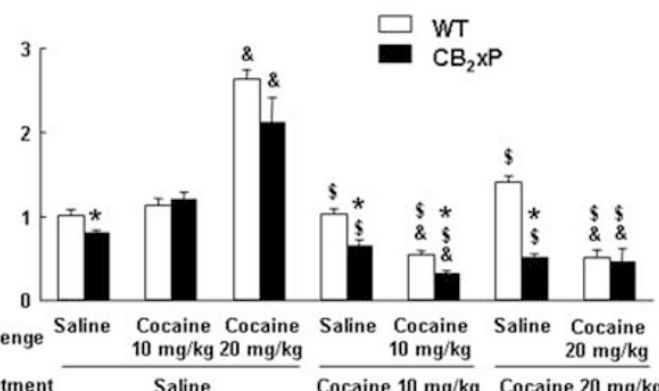

d

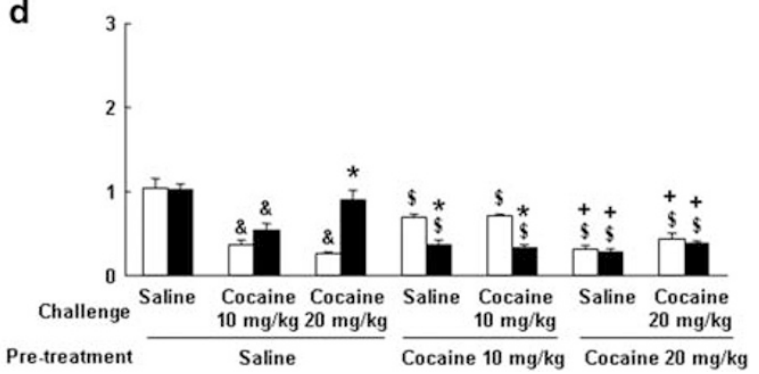

Figure 10 Changes in $\mu$-opioid and $C B_{1}$ receptor gene expression induced by cocaine in the nucleus accumbens $(N A c c)$ of $C B_{2} r$ overexpressing $\left(C B_{2} \times P\right)$ and wild-type $(W T)$ mice. (a, c) Columns represent the means and vertical lines + SEM of $2^{(-\Delta \Delta C t)}$ of relative $\mu$-opioid and $C B_{1}$ receptor gene expression, respectively, in WT and $\mathrm{CB}_{2} \times \mathrm{P}$ mice ( $n=6$ per group) measured in the NAcc under baseline conditions. (b, d) WT and $\mathrm{CB}_{2} \times P$ mice $(n=6$ per group) received a challenge of saline or cocaine $(10-20 \mathrm{mg} / \mathrm{kg})$, after 6 days of withdrawal from 20 days of pre-treatment with saline or cocaine $(10-20 \mathrm{mg} / \mathrm{kg})$. Columns represent the means and vertical lines + SEM of $2^{(-\Delta \Delta C t)}$ of relative $\mu$-opioid and $C B_{1}$ receptor gene expression in $W T$ and $C B_{2} \times P$ mice challenged with saline or cocaine. ${ }^{*} P<0.001$ vs WT, ${ }^{\&} P<0.05$ vs saline challenge, ${ }^{\$} P<0.05$ vs saline pre-treatment and, ${ }^{+} P<0.05$ vs cocaine pre-treatment $(I 0 \mathrm{mg} / \mathrm{kg})$.

expression compared with saline challenge $(P<0.05$; Figure 10d). There were different effects of the combination of pre-treatment and challenge dose $(P<0.001)$, and the interaction of these factors with genotype resulted statistically significant $(P<0.005)$. Thus, in saline pre-treated mice, cocaine challenge decreased less $\mathrm{CB}_{1} \mathrm{r}$ gene expression 
in $\mathrm{CB}_{2} \mathrm{xP}$ compared with $\mathrm{WT}$ mice. In contrast, cocaine challenge decreased more $\mathrm{CB}_{1} \mathrm{r}$ gene expression in cocaine pre-treated $\mathrm{CB}_{2} \mathrm{xP}$ mice compared with WT mice.

\section{DISCUSSION}

The present results provide evidence for the relevant role of the cannabinoid $\mathrm{CB}_{2} \mathrm{r}$ in the development of motor sensitization and the reinforcing effects of cocaine. This is supported by several observations: (a) $\mathrm{CB}_{2} \mathrm{xP}$ mice showed reduced motor response to acute cocaine $(10-20 \mathrm{mg} / \mathrm{kg})$ compared with WT mice; (b) motor sensitization induced by chronic cocaine administration was reduced in $\mathrm{CB}_{2} \mathrm{xP}$ mice; (c) $\mathrm{CB}_{2} \mathrm{xP}$ mice presented cocaine-induced conditioned place aversion; (d) cocaine self-administration was reduced in $\mathrm{CB}_{2} \mathrm{xP}$ mice; (e) $\mathrm{CB}_{2} \mathrm{xP}$ mice presented increased TH $(60 \%)$ and DAT $(88 \%)$ in the VTA and decreased $\mu$ opioid receptor $(25 \%)$ gene expression in the NAcc; and (f) the decrease in DAT gene expression in the VTA induced by a cocaine challenge in cocaine-sensitized mice was $50 \%$ lower in $\mathrm{CB}_{2} \mathrm{xP}$ compared with WT mice.

$\mathrm{CB}_{2} \mathrm{xP}$ and WT mice showed similar spontaneous motor activity. This finding was consistent with a previous study from our laboratory (Garcia-Gutierrez and Manzanares, 2011). The acute administration of cocaine enhanced the motor activity in both genotypes, although the response in $\mathrm{CB}_{2} \mathrm{xP}$ mice was significantly less pronounced. These attenuated motor effects were significant only with 10 and $20 \mathrm{mg} / \mathrm{kg}$ of cocaine, whereas the higher dose of cocaine $(40 \mathrm{mg} / \mathrm{kg})$ did not produce significant differences between genotypes. The changes found in $\mathrm{TH}$ and DAT gene expression could explain the different response to cocaine $(10-20 \mathrm{mg} / \mathrm{kg})$, however, it is possible that the elevated cocaine dose $(40 \mathrm{mg} / \mathrm{kg})$ induced a ceiling effect that precluded discriminating between both genotypes. On the other hand, we recently reported that deletion of $\mathrm{CB}_{2} \mathrm{r}$ increased the sensitivity to the motor responses of an acute dose of cocaine in the open field (Ortega-Alvaro et al, 2011).

Repeated exposure to psychostimulants produces sensitization, revealed by progressive enhancement of their hyperlocomotor effects (Robinson and Berridge, 1993, 2001). This motor sensitization remains after the withdrawal of the chronic psychostimulant treatment (Pierce and Kalivas, 1997). During the development of cocaineinduced motor sensitization, $\mathrm{CB}_{2} \mathrm{xP}$ mice showed less hyperlocomotion than WT mice, specifically at the dose of $20 \mathrm{mg} / \mathrm{kg}$, where differences between genotypes were statistically significant. These results point to the involvement of $\mathrm{CB}_{2} \mathrm{r}$ in the development of cocaine-induced motor sensitization in mice. Nevertheless, on days 1 and 20 of the sensitization protocol, $10 \mathrm{mg} / \mathrm{kg}$ of cocaine did not produce statistically significant differences in motor activity between genotypes, contrary to what was observed in the doseresponse study. The discrepancies found in this cocaineinduced motor response may be due to the limiting dose factor together with the specific features of the sensitization protocol. On day 0 , mice were habituated to the open field cage for a 20 -min period without treatment. This habituation process was not carried out in the dose-response study. Thus, the cocaine dose-response results are not comparable to the results of cocaine sensitization on days 1 and 10 . On the other hand, the challenge with cocaine at the high dose $(20 \mathrm{mg} / \mathrm{kg})$ markedly increased motor activity in cocaine pre-treated WT mice compared with saline pre-treated controls, whereas in $\mathrm{CB}_{2} \mathrm{xP}$ mice this effect was significantly lower. Thus, the expression of cocaine-induced sensitization may also be modulated by $\mathrm{CB}_{2} \mathrm{r}$ in mice.

The specific molecular mechanisms by which the overexpression of $\mathrm{CB}_{2} \mathrm{r}$ resulted in decreased cocaine-induced motor response and sensitization remain to be determined. The $\mathrm{CB}_{2} \mathrm{r}$ has been identified in the brain areas regulating motor functions such as caudate-putamen and substantia nigra (Garcia-Gutierrez et al, 2010; Gong et al, 2006), and alterations in dopaminergic and glutamatergic transmission have been closely related with the development of cocaine behavioral sensitization (Vanderschuren and Kalivas, 2000). Thus, it may be possible that the increased expression of $\mathrm{CB}_{2} \mathrm{r}$ in these brain areas resulted in alterations of the activity of these neurotransmitter systems decreasing motor responses to cocaine. In agreement, in this study specific changes in DAT and TH gene expression, key components of dopaminergic transmission, were found in $\mathrm{CB}_{2} \mathrm{xP}$ compared with WT mice. The gene expression of $\mathrm{TH}$ and DAT in the VTA were measured in both genotypes, under baseline conditions and following cocaine or saline challenge after 6 days of withdrawal from saline or cocaine chronic treatment. The acute cocaine administration in saline pre-treated groups will help to differentiate the changes in gene expression due to neuroadaptations after chronic cocaine treatment from those produced by a single cocaine injection in saline pre-treated animals. The results revealed that $\mathrm{CB}_{2} \mathrm{xP}$ mice presented higher $\mathrm{TH}(60 \%)$ and DAT (89\%) gene expressions than WT mice under baseline conditions. Acute cocaine administration in saline or cocaine pre-treated mice similarly decreased $\mathrm{TH}$ gene expression in both genotypes. On the other hand, the significant reduction in DAT gene expression occurring in cocaine pre-treated mice was less pronounced $(\sim 50 \%)$ in $\mathrm{CB}_{2} \mathrm{xP}$ than in WT mice, indicating that chronic administration of a high dose of cocaine induces less adaptive changes in DAT gene expression in the VTA of $\mathrm{CB}_{2} \mathrm{xP}$ than WT mice. As DAT deletion facilitates cocaine-induced sensitization (Morice et al, 2010), the enhanced DAT gene expression found in transgenic mice might act in an opposite manner, interfering on cocaine-induced sensitization.

$\mathrm{CB}_{2} \mathrm{xP}$ mice presented lower (25\%) $\mu$-opioid receptor gene expression than WT mice under baseline conditions in the NAcc. The cocaine challenge increased $\mu$-opioid receptor gene expression in the NAcc of saline pre-treated mice whereas it decreased the same in cocaine pre-treated mice. These changes occurred in a similar manner in both genotypes. These results suggest that the overexpression of $\mathrm{CB}_{2} \mathrm{r}$ has no consequences on cocaine-induced regulation of $\mu$-opioid receptors in the NAcc, although both genotypes presented differences in the $\mu$-opioid receptor baseline levels. On the other hand, $\mathrm{CB}_{1} \mathrm{r}$ gene expression in the NAcc under baseline conditions was similar in both genotypes. Cocaine challenge in WT mice pre-treated with saline significantly decreased $\mathrm{CB}_{1} \mathrm{r}$ gene expression, whereas this effect was not observed in $\mathrm{CB}_{2} \mathrm{xP}$ mice. In contrast, the cocaine challenge in cocaine pre-treated mice significantly decreased $\mathrm{CB}_{1} \mathrm{r}$ gene expression in $\mathrm{CB}_{2} \mathrm{xP}$ but not in $\mathrm{WT}$ 
mice. These results suggest that the pattern of cocaine administration (acute or chronic) differently affected $\mathrm{CB}_{1} \mathrm{r}$ gene expression in $\mathrm{CB}_{2} \mathrm{xP}$ and WT mice. This fact might be due to potential compensatory mechanisms between $\mathrm{CB}_{1} \mathrm{r}$ and $\mathrm{CB}_{2} \mathrm{r}$.

This study demonstrates the involvement of the cannabinoid $\mathrm{CB}_{2} \mathrm{r}$ in the actions of cocaine in the $\mathrm{CPP}$, as well as in the acquisition of intravenous cocaine self-administration. WT mice did not present a clear CPP for the conditioning compartment, whereas $\mathrm{CB}_{2} \mathrm{xP}$ mice showed cocaine-induced conditioned place aversion. The ratio of mice reaching the acquisition criteria in self-administration studies was reduced and the mean time to achieve these criteria was increased in the $\mathrm{CB}_{2} \mathrm{xP}$ group. An increased baseline gene expression of TH and DAT was revealed in $\mathrm{CB}_{2} \mathrm{xP}$ mice and the enhanced expression of DAT was maintained even after repeated cocaine administration. The reinforcing effects of cocaine are related to its ability to inhibit DAT (Di Chiara, 1995; Koob and Bloom, 1988; Kuhar et al, 1991). The enhanced DAT gene expression might account for the decreased perception of cocaine reinforcing effects in $\mathrm{CB}_{2} \mathrm{xP}$ mice and for the consequent impairment in the acquisition of cocaine self-administration. However, the role of DAT in cocaine reinforcing effects has also been questioned (Rocha et al, 1998; Sora et al, 2001). In spite of the decreased acquisition of cocaine self-administration in $\mathrm{CB}_{2} \mathrm{xP}$ mice, no differences in the motivation to obtain cocaine were observed between mice of both genotypes reaching the acquisition criteria. A similar dissociation between rates of acquisition and motivation for drug selfadministration has been previously reported in the mice with a different sensitivity to the reinforcing effects of the drug (Galeote et al, 2008; Trigo et al, 2009). Thus, $\mathrm{CB}_{2} \mathrm{r}$ overexpression interferes with the acquisition of cocaine self-administration behavior under a continuous schedule of reinforcement, but once this behavior is established, $\mathrm{CB}_{2} \mathrm{r}$ overexpression does not seem to affect performance on a progressive schedule of reinforcement, possibly suggesting that $\mathrm{CB}_{2} \mathrm{r}$ do not critically contribute to the motivational properties of cocaine. The deficits in cocaine self-administration observed in $\mathrm{CB}_{2} \mathrm{xP}$ mice cannot be attributed to possible unspecific learning or motor deficits produced by the $\mathrm{CB}_{2} \mathrm{r}$ overexpression as both genotypes similarly acquired and maintained stable operant responding for water.

It has been recently reported ( $\mathrm{Xi}$ et al, 2011) that pharmacological activation of $\mathrm{CB}_{2} \mathrm{r}$ attenuated the effects of cocaine on the enhancement of extracellular DA levels in the NAcc of WT mice. In the same study, blockade of $\mathrm{CB}_{2} \mathrm{r}$ elevated basal extracellular DA levels in the NAcc, whereas deletion of $\mathrm{CB}_{2} \mathrm{r}$ did not alter this measure. Our in vivo microdialysis studies did not reveal differences between genotypes with respect to basal DA extracellular levels in the NAcc or after acute cocaine administration at $15 \mathrm{mg} / \mathrm{kg}$. WT mice treated with $\mathrm{CB}_{2} \mathrm{r}$ agonists are not necessarily equivalent to mice overexpressing $\mathrm{CB}_{2} \mathrm{r}$ from the behavioral and neurochemical point of view. Indeed, the dose and duration of the pharmacological treatment may produce adaptive changes in the number and/or functional activity of the $\mathrm{CB}_{2} \mathrm{r}$ that could explain, at least in part, the neurochemical and behavioral responses. Besides, the genetic manipulation of the receptor may affect other neurochemical systems coupled with $\mathrm{CB}_{2} \mathrm{r}$ function in a different manner than the administration of the cannabinoid agonist in WT mice. In this respect, we have previously reported increased GABAA $\alpha_{2}$ and GABAA $\gamma_{2}$ gene expression in the hippocampus and amygdala of $\mathrm{CB}_{2} \mathrm{xP}$ mice (Garcia-Gutierrez and Manzanares, 2011). This enhancement of the GABAergic function could also regulate differently the cocaine-induced behaviors in $\mathrm{CB}_{2} \mathrm{xP}$ compared with WT mice.

The results of this study also revealed that $\mathrm{CB}_{2} \mathrm{r}$ are found in neurons and astrocytes in both genotypes. In addition, D2Dr i.r. cells were seen in the NAcc and VTA, which were also $\mathrm{CB}_{2} \mathrm{r}$ i.r. in both WT and $\mathrm{CB}_{2} \mathrm{xP}$ mice. These findings suggest that $\mathrm{CB}_{2} \mathrm{r}$ and $\mathrm{D} 2 \mathrm{Dr}$ are located in the same neurons of the NAcc and VTA. There is no information available regarding the functional cooperation between the $\mathrm{CB}_{2} \mathrm{r}$ and D2Dr. However, an interaction between 2arachidonoylglycerol and DA receptors has been described in rat NAcc core neurons mediating an enhancement of firing (Seif et al, 2011). Taken together, these results might provide a cellular mechanism to understand the important role of NAcc D2Dr and $\mathrm{CB}_{2} \mathrm{r}$ in the behavioral responses associated to the acquisition of drug-seeking behavior. Moreover, DA modulation of excitatory currents in the striatum controlled by the expression of D1Dr or D2Dr is modified by endocannabinoids (Andre et al, 2010), suggesting that activation of postsynaptic DA receptors controls endocannabinoid mobilization. The precise molecular mechanisms by which the $\mathrm{CB}_{2} \mathrm{r}$ may interact with the D2Dr remain to be determined.

In conclusion, the results presented here demonstrate that overexpression of $\mathrm{CB}_{2} \mathrm{r}$ reduced the effects of cocaine on motor sensitization, CPP and self-administration. Changes in DAT, $\mathrm{TH}$, and $\mu$-opioid receptor gene expression were found in the VTA or NAcc of $\mathrm{CB}_{2} \mathrm{xP}$ mice that may be involved, at least in part, in these distinct behavioral responses to cocaine. The results point out that pharmacological manipulation of the $\mathrm{CB}_{2} \mathrm{r}$ might be considered a new valuable target for the treatment of cocaine dependence. Further studies are needed to explore these hypotheses.

\section{ACKNOWLEDGEMENTS}

This research was supported by 'Instituto de Salud Carlos III' (RETICS, RD06/0001/1004), 'Plan Nacional Sobre Drogas' (PNSD 2007/061), Fundación para la Investigación en Salud Castilla La Mancha, FISCAM), and 'Ministerio de Ciencia e Innovación' (\#SAF 2008-01106 and \#SAF 201123420) to JM; by 'Instituto de Salud Carlos III' (RETICS, RD06/001/001), 'Ministerio de Ciencia e Innovación' (\#SAF2007-64062), and Generalitat de Catalunya (\#2009SGR00731 and the ICREA Academia award) to RM; and by the 'Ministerio de Ciencia e Innovación' (\#SAF2009-10689) to PB Postdoctoral fellows AO-A and AT are supported by FISCAM, and JMT by 'Becas para estancias cortas de especialización e investigación en psiquiatría y psicología de la infancia y adolescencia o en neurociencias' Fundación Alicia Koplowitz. AA-F (predoctoral fellow) and Analía Rico (AR, technician) are supported by RETICS. MSG-G is a predoctoral fellow supported by 'Ministerio de Ciencia e Innovación'. 
DN is a predoctoral FPI fellow. We thank AR for his excellent technical assistance, and Dulce Real for her contribution in the microdialysis and HPLC experiments. The partial support of FEDER funds (EU) is also acknowledged.

\section{DISCLOSURE}

The authors declare no conflict of interest.

\section{REFERENCES}

Andre VM, Cepeda C, Cummings DM, Jocoy EL, Fisher YE, William Yang X et al (2010). Dopamine modulation of excitatory currents in the striatum is dictated by the expression of D1 or D2 receptors and modified by endocannabinoids. Eur J Neurosci 31: 14-28.

Corbille AG, Valjent E, Marsicano G, Ledent C, Lutz B, Herve D et al (2007). Role of cannabinoid type 1 receptors in locomotor activity and striatal signaling in response to psychostimulants. J Neurosci 27: 6937-6947.

Cossu G, Ledent C, Fattore L, Imperato A, Bohme GA, Parmentier $\mathrm{M}$ et al (2001). Cannabinoid CB1 receptor knockout mice fail to self-administer morphine but not other drugs of abuse. Behav Brain Res 118: 61-65.

Chefer VI, Kieffer BL, Shippenberg TS (2004). Contrasting effects of mu opioid receptor and delta opioid receptor deletion upon the behavioral and neurochemical effects of cocaine. Neuroscience 127: 497-503.

De Vries TJ, Shaham Y, Homberg JR, Crombag H, Schuurman K, Dieben J et al (2001). A cannabinoid mechanism in relapse to cocaine seeking. Nat Med 7: 1151-1154.

Di Chiara G (1995). The role of dopamine in drug abuse viewed from the perspective of its role in motivation. Drug Alcohol Depend 38: 95-137.

Diana M, Melis M, Muntoni AL, Gessa GL (1998). Mesolimbic dopaminergic decline after cannabinoid withdrawal. Proc Natl Acad Sci USA 95: 10269-10273.

Ehrhart J, Obregon D, Mori T, Hou H, Sun N, Bai Y et al (2005). Stimulation of cannabinoid receptor 2 (CB2) suppresses microglial activation. J Neuroinflammation 2: 29.

Fattore L, Fadda P, Fratta W (2007). Endocannabinoid regulation of relapse mechanisms. Pharmacol Res 56: 418-427.

Filip M, Golda A, Zaniewska M, McCreary AC, Nowak E, Kolasiewicz W et al (2006). Involvement of cannabinoid CB1 receptors in drug addiction: effects of rimonabant on behavioral responses induced by cocaine. Pharmacol Rep 58: 806-819.

Gainetdinov RR, Bohn LM, Sotnikova TD, Cyr M, Laakso A, Macrae AD et al (2003). Dopaminergic supersensitivity in $G$ protein-coupled receptor kinase 6-deficient mice. Neuron 38: 291-303.

Galeote L, Maldonado R, Berrendero F (2008). Involvement of kappa/dynorphin system in the development of tolerance to nicotine-induced antinociception. J Neurochem 105: 1358-1368.

Garcia-Gutierrez MS, Manzanares J (2011). Overexpression of CB2 cannabinoid receptors decreased vulnerability to anxiety and impaired anxiolytic action of alprazolam in mice. J Psychopharmacol 25: 111-120.

Garcia-Gutierrez MS, Perez-Ortiz JM, Gutierrez-Adan A, Manzanares J (2010). Depression-resistant endophenotype in mice overexpressing cannabinoid $\mathrm{CB}(2)$ receptors. $\mathrm{Br} J$ Pharmacol 160: $1773-1784$.

Gong JP, Onaivi ES, Ishiguro H, Liu QR, Tagliaferro PA, Brusco A et al (2006). Cannabinoid CB2 receptors: immunohistochemical localization in rat brain. Brain Res 1071: 10-23.
Guzman ML, Upchurch D, Grimes B, Howard DS, Rizzieri DA, Luger SM et al (2001). Expression of tumor-suppressor genes interferon regulatory factor 1 and death-associated protein kinase in primitive acute myelogenous leukemia cells. Blood 97: 2177-2179.

Hall FS, Goeb M, Li XF, Sora I, Uhl GR (2004). mu-Opioid receptor knockout mice display reduced cocaine conditioned place preference but enhanced sensitization of cocaine-induced locomotion. Brain Res Mol Brain Res 121: 123-130.

Hummel M, Ansonoff MA, Pintar JE, Unterwald EM (2004). Genetic and pharmacological manipulation of $\mathrm{mu}$ opioid receptors in mice reveals a differential effect on behavioral sensitization to cocaine. Neuroscience 125: 211-220.

Ibrahim MM, Deng H, Zvonok A, Cockayne DA, Kwan J, Mata HP et al (2003). Activation of CB2 cannabinoid receptors by AM1241 inhibits experimental neuropathic pain: pain inhibition by receptors not present in the CNS. Proc Natl Acad Sci USA 100: 10529-10533.

Ishiguro H, Iwasaki S, Teasenfitz L, Higuchi S, Horiuchi Y, Saito T et al (2007). Involvement of cannabinoid CB2 receptor in alcohol preference in mice and alcoholism in humans. Pharmacogenomics J 7: 380-385.

Jaber M, Dumartin B, Sagne C, Haycock JW, Roubert C, Giros B et al (1999). Differential regulation of tyrosine hydroxylase in the basal ganglia of mice lacking the dopamine transporter. Eur J Neurosci 11: 3499-3511.

Jaber M, Jones S, Giros B, Caron MG (1997). The dopamine transporter: a crucial component regulating dopamine transmission. Mov Disord 12: 629-633.

Jones SR, Gainetdinov RR, Jaber M, Giros B, Wightman RM, Caron MG (1998). Profound neuronal plasticity in response to inactivation of the dopamine transporter. Proc Natl Acad Sci USA 95: 4029-4034.

Koob GF, Bloom FE (1988). Cellular and molecular mechanisms of drug dependence. Science 242: 715-723.

Kuhar MJ, Ritz MC, Boja JW (1991). The dopamine hypothesis of the reinforcing properties of cocaine. Trends Neurosci 14: 299-302.

Lesscher HM, Hoogveld E, Burbach JP, van Ree JM, Gerrits MA (2005). Endogenous cannabinoids are not involved in cocaine reinforcement and development of cocaineinduced behavioural sensitization. Eur Neuropsychopharmacol 15: 31-37.

Livak KJ, Schmittgen TD (2001). Analysis of relative gene expression data using real-time quantitative PCR and the 2(-Delta Delta C(T)) Method. Methods 25: 402-408.

Lupica CR, Riegel AC, Hoffman AF (2004). Marijuana and cannabinoid regulation of brain reward circuits. $\mathrm{Br} J$ Pharmacol 143: 227-234.

Maldonado R, Valverde O, Berrendero F (2006). Involvement of the endocannabinoid system in drug addiction. Trends Neurosci 29: 225-232.

Manzanares J, Corchero J, Romero J, Fernandez-Ruiz JJ, Ramos JA, Fuentes JA (1999). Pharmacological and biochemical interactions between opioids and cannabinoids. Trends Pharmacol Sci 20: 287-294.

Martin M, Ledent C, Parmentier M, Maldonado R, Valverde O (2000). Cocaine, but not morphine, induces conditioned place preference and sensitization to locomotor responses in CB1 knockout mice. Eur J Neurosci 12: 4038-4046.

Miller LL, Ward SJ, Dykstra LA (2008). Chronic unpredictable stress enhances cocaine-conditioned place preference in type 1 cannabinoid receptor knockout mice. Behav Pharmacol 19: 575-581.

Morice E, Denis C, Giros B, Nosten-Bertrand M (2010). Evidence of long-term expression of behavioral sensitization to both cocaine and ethanol in dopamine transporter knockout mice. Psychopharmacology (Berl) 208: 57-66. 
Navarro M, Carrera MR, Fratta W, Valverde O, Cossu G, Fattore L et al (2001). Functional interaction between opioid and cannabinoid receptors in drug self-administration. J Neurosci 21: 5344-5350.

Nestler EJ (2001). Molecular basis of long-term plasticity underlying addiction. Nat Rev Neurosci 2: 119-128.

Oliva JM, Ortiz S, Palomo T, Manzanares J (2003). Behavioural and gene transcription alterations induced by spontaneous cannabinoid withdrawal in mice. $J$ Neurochem 85: 94-104.

Onaivi ES (2006). Neuropsychobiological evidence for the functional presence and expression of cannabinoid CB2 receptors in the brain. Neuropsychobiology 54: 231-246.

Onaivi ES (2008). An endocannabinoid hypothesis of drug reward and drug addiction. Ann N Y Acad Sci 1139: 412-421.

Onaivi ES, Ishiguro H, Gong JP, Patel S, Meozzi PA, Myers L et al (2008). Brain neuronal CB2 cannabinoid receptors in drug abuse and depression: from mice to human subjects. PLOS ONE 3: e1640.

Ortega-Alvaro A, Aracil-Fernandez A, Garcia-Gutierrez MS, Navarrete F, Manzanares J (2011). Deletion of CB2 cannabinoid receptor induces schizophrenia-related behaviors in mice. Neuropsychopharmacology 36: 1489-1504.

Paldyova E, Bereczki E, Santha M, Wenger T, Borsodi A, Benyhe S (2008). Noladin ether, a putative endocannabinoid, inhibits muopioid receptor activation via CB2 cannabinoid receptors. Neurochem Int 52: 321-328.

Palkovits M (1983). Punch sampling biopsy technique. Methods Enzymol 103: 368-376.

Parolaro D, Rubino T (2008). The role of the endogenous cannabinoid system in drug addiction. Drug News Perspect 21: 149-157.

Paxinos G, Franklin KBJ (2001). The Mouse Brain in Stereotaxic Coordinates. Academic Press, Harcourt Science and Technology Company: New York.

Pierce RC, Kalivas PW (1997). A circuitry model of the expression of behavioral sensitization to amphetamine-like psychostimulants. Brain Res Brain Res Rev 25: 192-216.

Racz I, Nadal X, Alferink J, Banos JE, Rehnelt J, Martin M et al (2008). Crucial role of $\mathrm{CB}(2)$ cannabinoid receptor in the regulation of central immune responses during neuropathic pain. J Neurosci 28: 12125-12135.

Robinson TE, Berridge KC (1993). The neural basis of drug craving: an incentive-sensitization theory of addiction. Brain Res Brain Res Rev 18: 247-291.

Robinson TE, Berridge KC (2001). Incentive-sensitization and addiction. Addiction 96: 103-114.

Robledo P, Mendizabal V, Ortuno J, de la Torre R, Kieffer BL, Maldonado R (2004). The rewarding properties of MDMA are preserved in mice lacking mu-opioid receptors. Eur J Neurosci 20: $853-858$.

Rocha BA, Scearce-Levie K, Lucas JJ, Hiroi N, Castanon N, Crabbe JC et al (1998). Increased vulnerability to cocaine in mice lacking the serotonin-1B receptor. Nature 393: 175-178.
Seif T, Makriyannis A, Kunos G, Bonci A, Hopf FW (2011). The endocannabinoid 2-arachidonoylglycerol mediates D1 and D2 receptor cooperative enhancement of rat nucleus accumbens core neuron firing. Neuroscience 193: 21-33.

Sora I, Hall FS, Andrews AM, Itokawa M, Li XF, Wei HB et al (2001). Molecular mechanisms of cocaine reward: combined dopamine and serotonin transporter knockouts eliminate cocaine place preference. Proc Natl Acad Sci USA 98: 5300-5305.

Soria G, Mendizabal V, Tourino C, Robledo P, Ledent C, Parmentier $\mathrm{M}$ et al (2005). Lack of CB1 cannabinoid receptor impairs cocaine self-administration. Neuropsychopharmacology 30: $1670-1680$.

Spanagel R, Weiss F (1999). The dopamine hypothesis of reward: past and current status. Trends Neurosci 22: 521-527.

Tanda G, Goldberg SR (2003). Cannabinoids: reward, dependence, and underlying neurochemical mechanisms-a review of recent preclinical data. Psychopharmacology (Berl) 169: 115-134.

Tanda G, Pontieri FE, Di Chiara G (1997). Cannabinoid and heroin activation of mesolimbic dopamine transmission by a common mul opioid receptor mechanism. Science 276: 2048-2050.

Trigo JM, Orejarena MJ, Maldonado R, Robledo P (2009). MDMA reinstates cocaine-seeking behaviour in mice. Eur Neuropsychopharmacol 19: 391-397.

Trigo JM, Renoir T, Lanfumey L, Hamon M, Lesch KP, Robledo P et al (2007). 3,4-methylenedioxymethamphetamine self-administration is abolished in serotonin transporter knockout mice. Biol Psychiatry 62: 669-679.

Urigüen L, Pérez-Rial S, Ledent C, Palomo T, Manzanares J (2004). Impaired action of anxiolytic drugs in mice deficient in cannabinoid CB1 receptors. Neuropharmacology 46: 966-973.

Van Sickle MD, Duncan M, Kingsley PJ, Mouihate A, Urbani P, Mackie $\mathrm{K}$ et al (2005). Identification and functional characterization of brainstem cannabinoid CB2 receptors. Science 310: 329-332.

Vanderschuren LJ, Kalivas PW (2000). Alterations in dopaminergic and glutamatergic transmission in the induction and expression of behavioral sensitization: a critical review of preclinical studies. Psychopharmacology (Berl) 151: 99-120.

Xi ZX, Peng XQ, Li X, Song R, Zhang HY, Liu QR et al (2011). Brain cannabinoid CB receptors modulate cocaine's actions in mice. Nature neuroscience 14: 1160-1166.

Xi ZX, Spiller K, Pak AC, Gilbert J, Dillon C, Li X et al (2008). Cannabinoid CB1 receptor antagonists attenuate cocaine's rewarding effects: experiments with self-administration and brain-stimulation reward in rats. Neuropsychopharmacology 33: $1735-1745$.

Yoo JH, Yang EM, Lee SY, Loh HH, Ho IK, Jang CG (2003). Differential effects of morphine and cocaine on locomotor activity and sensitization in mu-opioid receptor knockout mice. Neurosci Lett 344: 37-40.

Supplementary Information accompanies the paper on the Neuropsychopharmacology website (http://www.nature.com/npp) 